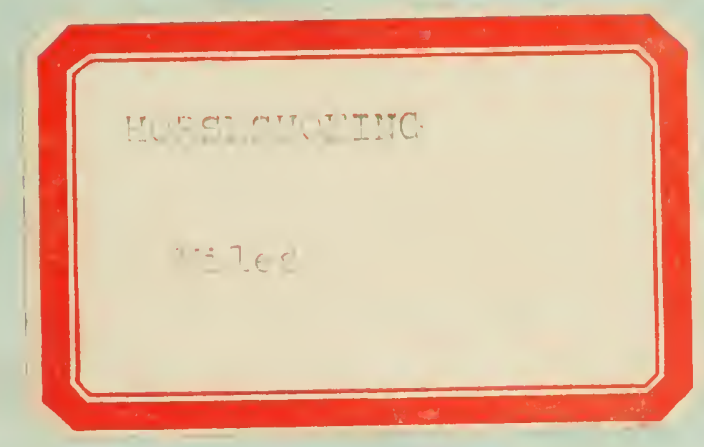




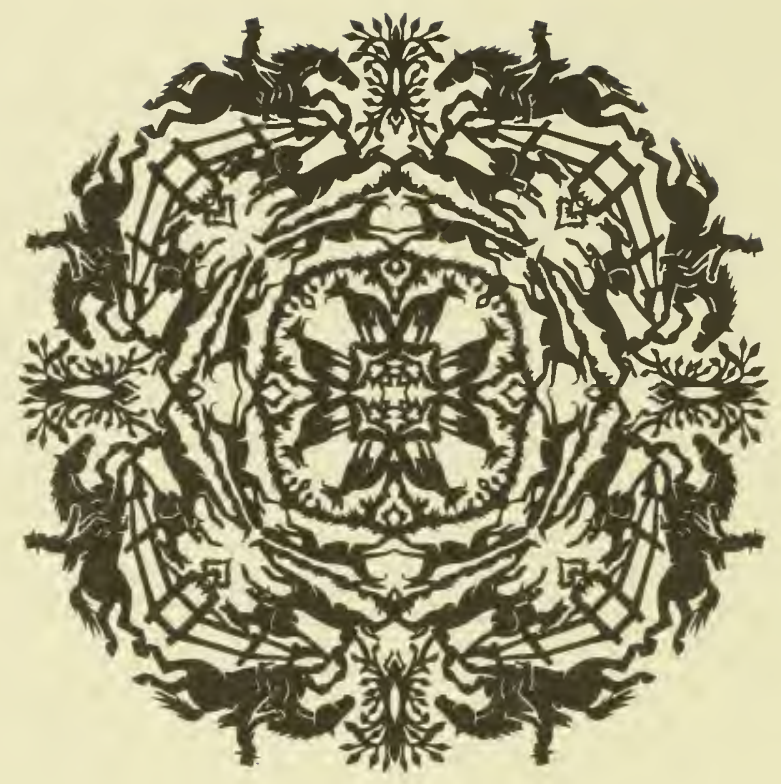

JOHN A.SEAVERNS 


\section{[NEW SERERS $]$}

$0 N^{\circ}$

\section{HOR SESHOEING.}

$\mathbf{B X}$

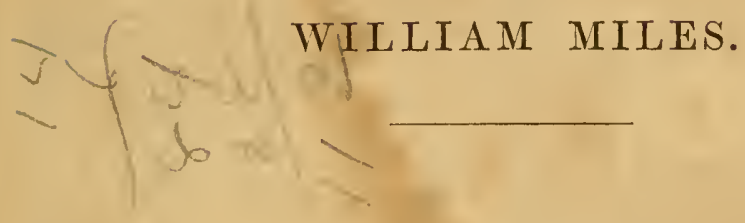

REPRINTED, FOR GENERAL DISTREUTION, FROM THE JOURNAL OF THE ROYAL AGRICULTURAL SOCLETX OF ENGLAND. VOL. 18, P. 270.

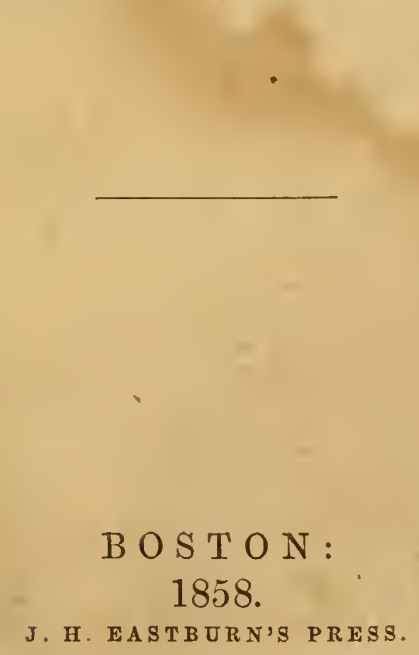





\section{O R S E S H OEING.}

Althougn the subject of this paper may not legitimately come under the head of agriculture, it is nevertheless so intimately connected with the interests of the agriculturist, and has been so wofully neglected by him, that I may perhaps be excused for attempting to arouse him to a sense of its inportance in a pecuniary point of view. Horses are essential to the carrying on of his pursuits, he cannot possibly do without them, and a lame one is a very serious and expensive incumbrance to lim.

My object, therefore, shall be to show him and others how they may insure to themselves a much larger amount of good and efficient service from their horses than has hitherto been obtained from them, at the small cost of a little attention to the mode in which they are shod, and the general treatment of their feet in the stable. It is too much the habit to consider that shoeing has accomplished all that can be expected of it, if the shoes are only firm on the horse's feet when his master requires his services; whether they are tight and pinch lim, or are easy and comfortable to him, are matters that are seldom considered, so long as he can go at all, and contrive to keep himself on his legs, and not diminish his marketable value by tumbling down and breaking his knees; all the pain he endures passes unheeded, except by the poor brute himself, and until he becomes positively lame and useless he receives no sympathy or care from those whose bounden duty it was by timely attention to have spared him. "No foot no horse" is a truth that I doubt not has been realized to many of my readers, when, in the expectation of an agreeable ride eitluer on business or pleasure, they have found their horse emerge from the stable, marking time with his head at every step with the precision of a drill-sergeant.

The first thing that occurs to every one on such occasions is to travel yesterday's journey over again in the mind's eye, in the hope of discovering some particular hole in the road, or some particular stone that must liave caused the unlooked for and unexpected calamity; the bare possibility of its being the gradually developed result of long continued bad shoeing, and bad treatment in the stable, of course never suggests itself, because the horse has always been treated as other horses are treated, and therefore those things can have nothing whatever to do with it; and this would be considered a sufficient and satisfactory answer to any one who had the temerity to surmise such a cause. I will nevertheless venture to assert, that in nine hundred and ninety-nime cases of foot-lameness out of every thousand, bad shoeing and bad stabling have had more to do with it, than the supposed accident that causes the horse to " drop his head to it," and thereby show that the culminating point had at last been reached, and that he is indisputably lame. 
Foot-lameness is a very insidious affair, particularly that most painful and common form of it, navicular lameness. It steals on very gradually, and for the most part unobserved by all but the unfortunate horse; he, poor beast, notes its every stage, and if those who look after him, and those who employ him, would only attend to the indications he gives them, they would know as much abont it as he does, excepting the pain. His courage enables him to bear a good deal without much flinching, nevertheless he soon shows to a close observer that mischief is brewing; the first indication he gives is the straightening of the pastern bone, so as to place the weight of the leg more on the coffin bone, and less on the navicular bone; then, as time goes on, and the pain increases, he relaxes the fetlock joint, and bears less weight on the foot altogether; still there is not much in his mode of standing to attract the attention of a casual observer; his next plan for obtaining relief is to advance the foot slightly, so as to bring the toe of the lame foot a little in front of the toe of the opposite foot, whereby he removes it in some degree from the base which supports his weight.

All this may have been going on for months, and no one have observed it, until at last he can bear the pain no longer, and he thrusts his foot fairly ont in front of him in undisguised "pointing;" nevertheless he contrives, when he is at work, by shortening his stride and stepping a little quicker, to conceal the lameness; and the groom and his master become in time so accustomed to his posture in the stable, that they look upon it as a mere trick, and say, "it is all nothing, he always stands so when at rest:" the latter may be true, but the former is something more than doubtful.

Some horses are unquestionably given to tricks, but no horse ever indulges in a trick which compels him to stand almost constantly on two legs instead of four; the pain and inconvenience of such a proceeding would soon induce lim to relinquish it as a matter of amusement. Before he can point a fore foot lie is obliged to dispense with the support of the opposite hind leg, which he does by relaxing the muscles, lowering the hip, bending the joints, and resting the limb on the toe; he then has to divide his weight as equally as he can between the other hind leg and the opposite fore leg, and having done this he raises the lame foot and deposits it sufficiently forward to insure its exemption from sustaining any portion of his weight; he then lowers his head and neck with a view of still further diminish. ing the weight on his feet, and presents altogether such a picture of misery, that it would require a very lively imagination in the beholder to suppose the horse is merely indulging himself in an agreeable trick.

'The horse's foot is made up of a variety of textures so elaborately and beautifully combined as to form one complicated but perfect spring, and unless that spring is permitted to have constant freedom of action, it very soon gets out of order, the more delicate parts lose their elasticity, and the power of expansion, which is so essential to the soundness of the foot, becomes first diminished, and ultimately destroyed, whereby the horse is soon rendered useless. I take it there are few persons who will dispute the expansion of the horse's 
foot, but whatever the general theory about it may be, the all but universal practice is to treat it as an inelastic solid, whose chief use is to pound MacAdamized roads.

The horse in a state of nature roams about at will with his feet unfettered, and they take no harm, simply because he is permitted to look where he is going, pick his way over difficult ground, and direet his own pace; but as soon as he enters the service of man these valuable privileges and safeguards are withdrawn, and the various uses to which he is put, and the rapid rate at which he is required to travel over all sorts of roads, eall for some efficient protection to his feet, and it is not only our duty, in return for the important services he renders, to see that it is applied in the mamer the least detrimental to him, but it is our interest to do so in anticipation of the lengthened service it will insure to us. If horses were always properly shod, and properly stabled, they wonld rejay the care thus bestowed on them by the increased length of efficient service they would perform. When a horse has worked seven or eight years it is no uncommon thing to hear his master say, "he owes me nothing," which may be perfectly true, considering the treatment he has received; but if he had been properly treated during the time he would be still some eight or ten years of active service in his master's debt.

The horse is a mueh longer lived animal than people generally suppose him to be; but the prevalent mistake as to the length of his natural life may be attributed to two opposite causes: First, the very large number that are known to die at an early age-victims, it may truly be said, of over-work, bad management, and cruel treatment; and next, the great difficulty there always is of ascertaining the real age of a horse when the mark has disappeared from lis mouth. Horses are marketable commodities, and very few persons are disposed to lessen their value, by recording very accurately the number of years that pass over their heads, after the mark is gone; the consequence is, that they remain about nine or ten years old so long, that their aetual age becomes buried in oblivion, and at last no one really does know how old they are. Many a man at this moment is using a horse, perhaps some eight or ten years older than he thinks he is. I remember many years ago purchasing an active showy horse, said to be about the mysterious age of other people's horses, and there was nothing in his appearance or powers of work to indicate greater age; but on tracing his history I discovered that he was twenty-nine years old, and the sire of a very large progeny. Now, if I had not taken the trouble to trace him back I should never have known within fifteen or sixteen years how old he really was.

I liave, at different times, met with four horses who were all known to be over forty years old, and were still at work; one of them was shot at the age of forty-five, not because he was ineapable of further work, but because his master saw the servant ill use him. But, perhaps without taxing my memory for further facts, those supplied by my own stable in November of last year may sufliciently illustrate my position, that the natural life of a horse is longer than it is generally supposed to be. I had at that time six horses in my stable whose combined ages amounted to one hundred and forty-five years 
and five of them are still there, with elean legs and hoofs looking like colts' hoofs. The sixth I had destroyed last December at the age of twenty-six. When $I$ purchased him nineteen years ago he had incipient navicular disease, but I contrived by shoeing and stable management to keep it at bay all that time.

The patriareh of the lot, who was bred only five miles from Exeter, has just completed his fortieth year; his early history does not redound to his eredit; he was a very unruly, unmanageable brute, and was perpetually changing masters for running away and kicking carriages to pieces; two hackney men in succession tried him, but were obliged to part with him; at length he was handed over to the tender mercies of a commercial traveller, whose long journeys through Devon and Cornwall, after a few years, subdued him, and he became a very useful horse, and at the age of fourteen was sold to a friend of mine, from whom I purehased him exactly twenty years ago. He is a high stepper and remarkably handsome, and if you do not look in his mouth his general appearance would pass muster for nine or ten years old; he is perfectly quiet out of the stable, but he had been so teazed and worried all his life, until he came into my hands, that even now he will not permit a stranger to enter his box alone. The next in seniority is twenty-nine years old, and is the best hack I ever rode. Seventeen years ago, the smith who usually shod him declared his feet to be so far gone that he could shoe him no longer; and he was on the point of being shot, as "used up," and "quite done for," when I came to the rescue, and accepted him as a present, with the view of trying what I could do to put him on his feet again, and the result of my trial has been seventeen years of very efficient service.

There is no speciality attending the history of the other three : one is twenty-one years old, and has been in my possession sixteen years; another is sixteen years old, and has been in my possession nine years; and the last of the six above-named horses is thirteen years old, and I have had him eight years. The horse I purchased to replace the one that was shot in December is seven years old, and was in hard work up to the time I bought him, and although he has been only five months in my possession, his feet and legs have wonderfully improved, and begin to resemble those of my other horses.

If I were asked to account for my horses' legs and feet being in better order than those of my neighbors, I should attribute it to the four following circumstances: First, that they are all shod with few nails, so placed in the shoe as to permit the foot to expand every time they move; secondly, that they all live in boxes instead of stalls, and can move whenever they please; thirdly, that they have two hours daily walking exereise when they are not at work; and fourthly, that I have not a head-stall or rack-chain in my stable: these four circumstances comprehend the whole nystery of keeping horses' legs fine, and their feet in sound working condition up to a good old age. Another case occurs to me, where the same result has followed similar treatment in a mare $I$ purehased for a friend twelve years ago ; she was twelve years old when I bought her, and had done a great deal of work; she has ever since been shod by the smiths who shoe my horses, has lived in a loose box, is never tied up, and continues to 
do her work as pleasantly as ever she did. I may mention, in confirmation of the fact, that my horses are never tied up; that a short time ago a veterinary surgeon, who had occasion to apply a liniment to the throat of one of them, asked for a halter, and learnt to his astonishment that there was not one in the stable; we substituted a watering bridle, and afterwards fastened the horse to the pillar reins, to prevent his rubbing his neck, instead of adopting the usual plan of tying him short by the head to the wall: a watering bridle is at all times preferable to a halter either for commanding or leading a horse.

I am often assured, when talking of shoeing, that it is quite impossible to persuade country smiths to listen for a moment to any new suggestion, or to adopt any new plan, that they are an obstinate prejudiced race, and nothing can induce them to relinquish any of their old notions. I can only say in reply, that this does not at all accord with my experience of them as a class; on the contrary, I have found them, for the most part, to be hard-working; painstaking men, evincing great interest in their work, and anxious to do it as well as they could. I do not mean to say that there are no exceptions, because I know there are; but the exceptions do not disprove the rule.

Before we consent to condemn them in a body let us see how the matter really stands between them and their employers, who accuse them of prejudice and obstinacy. We must not forget that they have been accustomed from the period of their apprenticeship to shoe horses in one particular manner, which has hitherto given satisfaction, and, as far as they know to the contrary, they have never lamed a horse.

We must not be surprised, if, under these circumstances, they should show great reluctance to relinquish plans which long habit has rendered almost second nature to them, or if they require to be thoroughly convinced of the practicability and superiority of a new plan, before they consent to give up the old one; and as it is much more difficult to eftace what has been already learnt than to teach what is new, he who undertakes to become an instructor, must at least be sufficiently master of his subject to be able to point out pretty clearly the advantages of the plan he proposes over that which he desires to alter; to which end he must acquaint himself with the details of his plan before he ventures into the forge, for an intelligent smith will make a very accurate estimate of his fitness to teach before he has been many minutes there; and I have no doubt but much of the obstinacy and perversity one hears of may be traced to the smith's having received impracticable, if not impossible, directions. And surely it is not very unreasonable in him to object to earry out details which he does not comprehend, and which he strongly suspects his instructor is not very clear about, when he knows full well that he would decline to share the blame with him, in case the experiment should fail, and the horse cast a shoe.

I have been sometimes surprised at the readiness with which smiths have yielded their opinion to me, as soon as they found that I really knew what I was talking about, and that I could not only give them 
directions, but show them exactly how to carry them out in detail, and, if $Y$ had only possessed the brawny arm which is necessary for such a purpose, that I conld have forged the shoe and fitted it to the foot. They all feel that horseshoeing is open to improvement, and as a class they are anxions for information that they can depend on, but they are naturally very shy of relinquishing plans which they have been long accnstomed to for others which they do not comprehend; but any gentleman who will take the trouble to acquaint himself with the principle and details of the plan which I advoeate, will very soon become a welcome visitor at the forge, and while he is improving the condition of his own horses' feet, he will find that he is indoctrinating the whole district to the great benefit of his neighbors; for although they will not take tronble themselves, they are soon ready to avail themselves of the trouble taken by others, and will send their horses to the man who can shoe them best, and that causes the other smiths to look about them and change their plans.

A few years ago I rented a honse for the summer near to a country village, and was very soon waited on by the smith with specimens of his shoes, and a foot shod in his very best manner; and as examples of careful finish they were very pretty things to look at; but when I descended from the ornamental to the useful, and began to point out the defects one after the other, he looked astonished, and not very well pleased; he was, however, somewhat consoled by my telling him that I would have one of my horses brought to his forge on the following morning, and then I would show him what I meant. I kept my word, and finding that he entered with interest into my views, and tried his best to understand and carry them out, I took some tronble with him, and freqnently looked in and directed him at his work. One day I found him turning store-shoes of a better form than any $I$ had yet seen in his forge, and observing to him that they were more like what I meant, he said, "Oh yes, I have got it now, Sir ; my shoes were all too short to fit as they ought to do ;" and pointing to some that were hanging against the wall, he added, "before you came here I used to feel very proud of those shoes, but now it makes me ill to look at them, and I don't think I could ever make one like them again." He had become a really good shoer, and understood how to fit a shoe properly, and I think he wonld have found it a difficult job to fall back on his old pattern again. His fame soon spread, and he obtained the shoeing of all the gentlemen's horses for several miles around him. Similar results have followed in other instances where I have bestowed a little trouble, and I must say that I have invariably received civility and attention at the time and on many occasions expressions of great gratitude afterwards.

Many persons have been deterred from interfering with the smith, because, as they have told me, they knew nothing whatever about the anatomy or physiology of the horse's foot, and had neither the time nor the inclination to study it; but such knowledge is not at all necessary to a thorough acquaintance with the principle and practice of horseshoeing; if it were, they might well be excused for not attempting it: all that is really required of them is to take one anatomical and one physiological fact on trust, and believe that the horse's 
hoof is lined by a very sensitive membrane, which mush ever be wounded, and that the hoof itself is elastie, and è the weight of the horse is thrown on the foot, and coutrac taken oft" argain; all the rest is purely mechanical and merely the exercise of a little thought and patience to understand the ple and apply it.

liut before I enter on details let me dispose of one subject that has given rise to much unnecessary thought and controversy-I mean the very generally entertained notion, that particular kinds of roads and certain kinds of work call for separate and distinct methods of shoeing-which has greatly complicated and mystified a very simple and straightlorward matter: the truth is, that no system of shoeing is worth one moment's thought or consideration that will not answer equally well in every. description of ground, and for every kind of work.

It has been supposed that the hunter forms a special exception, but the experience of a large number of gentlemen in various parts of the country during the last ten years has entirely dispelled the fallacy, and prosed beyond dispute that the torture inflicted on hunters by nailing the shoes from heel to heel, with a riew of keeping them on their feet, is an unnecessary act of eruelty perpetrated to support the notion, that deep ground would pull the shoes off unless they were secured by extra nails: but if a shoe fits the foot as it onght to do, and is perfectly fastened to it by five nails, nothing short of a violent wrench from the smith's pincer's can remove it. This has been proved in numberless instances, not only by myself but by others in various hunting comntries, who lave kindly communicated to me the result of their experience after a fair trial of the plan of shoeing and general treatment of the horse's foot, which I recommended in a work I published some year's ago on that subject, and which an officer of P'ussian Ifussars desired my permission to translate and publish in German; and he writes me that he and several of lis brother officers have had their horses shod as I have directed, and that they never lost a shoe. It would be a useless waste of time to go over all the proofs again; nevertheless, as I am now writing for agricultural readers, it is desirable that $I$ should be able to show to them, beyond the possibility of doubt, that the mode of shoeing which I recommend will stand the test of the deep clay ground their horses are sometimes called upon to work in; and in order to qualify myself to speak with authority in this matter, I have lately instituted an experiment which I think will carry conviction to the nind of the most sceptical.

The two subjects of my experiment were horses employed in drawing materials for a large public building in course of erection in a deep clay meadow, and I chose the particular time for making the experiment, because the unusual quantity of rain that had fallen during the preceding six weeks had rendered the ground, both in the meadow and at the quarry from which the stone was drawn, as deep and clinging as it is possible to conceive ground to be. One of the horses was the property of the builder, and the other belonged to the person who had contracted to draw the stone from the quarry, and whose horses are chiefly employed in drawing either timber or stone, 
than which no work can be more trying to the security of horses' shoes at such a season, and in such a county as Devon. I was present at the shoeing of these horses, and saw them both shod with five nails only in each fore shoe and a clip at the toe. The shoes were plain waggon-horse shoes, with stamped holes and no fullering. The builder's horse was a fair average cart horse 15 hands $3 \frac{1}{2}$ inches high, and the shoes that were put on him weighed $1 \mathrm{lb} .14 \mathrm{ozs}$. each. 'The contractor's horse was a lieary waggon horse 16 hands and an inch high; and I could scarcely have found a fairer subject for my experiment: he has remarkably weak feet, with hoofs full of what smiths call shaky places, and he is so hot and impetuous in his work that the driver never can prevent him doing much more than his share. I had one of his shoes measured and weighed just before it was nailed on, and found it to be 6 inches across from side to side at the quarters, and 7 inches from toe to heel, and it weighed exactly $2 \frac{1}{2} \mathrm{lbs}$., so that each nail in his shoe had to retain lialf a pound weight of iron and hold it to his foot.

I visited both the horses at the end of a fortnight, and found their shoes not only safe on their feet, but not a clench had risen, neither had either of their shoes shifted in the smallest degree. I was fortunate enough to meet the larger horse coming from the quarry with a load of stone, and anything more satisfactory to me, as regarded my experiment, or less satisfactory to the poor brute, I cannot conceive; for he was literally plastered up to the knees and hocks with a thick layer of red clay, and the spokes of the wheels were in a like condition up to the nave, showing pretty clearly the kind of ground he had had to deal with, and the sort of test that had been applied to the security of his shoes.

At the expiration of another fortnight $I$ again examined the shoes of both the horses, and finding those of the larger horse completely worn ont, I had them taken off and replaced by new ones fastened by five nails; the shoes of the other horse not being worn out, I permitted him to carry them another week, and then, considering he had worn them long enough for my purpose, I had him reshod; but wishing to make my experiment as perfect as I could, I had two of the nails omitted, and shod him with three nails only in each fore shoe; and at the end of four weeks I saw him at work with his shoes safe on his feet. I do not mention this fact with the view of trying to persuade others to sloe their horses with only three nails, although I have not had more than three nails in a fore shoe of any horse belonging to me for several years past, neither do I intend to increase the number: I merely record the fact to show that no one need fear to trust their horses' shoes to the keeping of five nails.

The result of the numberless experiments I have made at various times, on all sorts of horses doing every kind of work, is, that there is but one principle to be observed in horseshoeing, which will admit of no variation or compromise: the shoe must fit the foot, whatever the shape of the foot may happen to be, and it must be nailed to the hoof in such a manner as will permit the foot to expand to the weight of the horse; this latter condition will be best complied with by placing three nails in the outer limb of the shoe, and two in the inner limb 
between the toe and the commencement of the inner quarter; a larger number thin five nails ean never be required in any shoe of any size, or under any circumstances, excepting for the sole purpose of counteracting defective and clumsy fitting. I will now proceed to describe, as shortly as I can, the details of the plan I recommend; and if it should appear, to those who have done me the honor to read what I have already published, that I have repeated myself; I can only answer that the details, of a fixed plan will admit of no variation in substance, and very little in words.

The first thing requiring attention is the removal of the old shoes, which should be done with much more care than is usually bestowed on it, and without any of that riolent wrenching from side to side one too often witnesses, whereby the elenches are dragged through the crust by main foree, and the horn wantonly and unnecessarily destroyed. It is very little trouble to raise-the clenches with the buffer, and, if the nails should still retain a firm hold and resist a moderate effort to displace the shoe, the punch should be used to loosen them, so as to cause the shoe to come off easily and without damage to the hoof. The smith will be amply repaid for his trouble by the unbroken horn he will find to nail to, and the firmer hold he will obtain for his nails when he comes to nail on the new shoe. Having taken off the shoe the rasp should be passed round the lower edge of the crust before the foot is let down, to remove the jagged edge, and also to ascertain that there are no stubs remainiug in the horn: if the edge is not rasped it is apt to split and break when the horse moves, which he is sure to do as soon as his foot is on the ground again. No horse should have more than one foot bared at a time; however strong his feet may happen to be, he is sure to stand quieter on a shod foot than he can on a bare one, and it will prevent his breaking the crust. A horse with weak flat feet is in positive misery when forced to sustain his whole weight on a bare foot, while the opposite foot is held up.

Previous to preparing the foot for the reception of the new shoe, we must consider, first, the kind of foot we have to deal with; and next, the condition of the roads it will have to travel upon; for it would be manifestly improper to pare a weak flat sole as much as a strong arched one, or to pare either as much when the roads are hard and covered with loose stones as when they are moist and even. No general rule, therefore, can be laid down that would apply to all kinds of feet, or indeed to the same foot at all times; the amount of paring the foot is to undergo must entirely depend on the above considerations.

A strong foot with an arched sole, when the roads are in good order, will require to have the toe shortened, the quarters and lieels lowered, and the sole pared, until it will yield in some slight degree to very hard pressure from the thumb; but on no account should it ever be pared thin enough to yield to moderate pressure: the angles formed by the crust, and the bars at the heels, must be cleared out, and all the dead horn removed therefrom, and the bars should be lowered nearly to a level with the sole.

A weak flat foot, on the contrary, will bear no shortening of the 
toe, and rery little paring or lowering anywhere; the heels of such feet are sure to be too low already, and the sole too thin : in fact, the less that is done to them the better beyond clearing out the dead horn from the angles at the heels, and making the crust bear evenly on the shoe; but the hollow between the bars and the frog, or the frog itself, must never be tonched by a knife in any foot, whether it be a weak one or a strong one, and as these latter directions differ so materially from the usual practice of smiths, I may perhaps be expected to state my reasons for wishing to enforee them in opposition to what they no donbt consider a time-honored custom; I mean, the inveterate habit they all have of trimming the frog, and opening out the heels at every shoeing; but I think I shall be able to show, that "it is a custom more honored in the breach than the observance."

The bars are not separate and distinet portions of the hoof, but simply continuations of the crust reflected or turned back at each heel in the direction of the centre of the sole, where they meet in a point and form a triangular space for the reception of the elastic cushion, usually called the sensible frog: each of these reflected portions, at its deepest part, rises about an inch into the cavity of the hoof, and is connected at its upper part, throughout its whole extent, on one edge with the horny sole, and on the other with the liorny frog, whereby the lorny covering of the foot is completed and made continuous. This doubling back of the crust on each side, from the heel to the point of the frog, togetler with the increased thickness of the crust itself at the extremity of each heel, is evidently designed to lieep the heels apart, and prevent their pressing inconveniently on the structures within the hoof; and if the substance of the horn be thinned by paring the sides of it, it is clear that its power of resistance must be diminished, the natural action of the foot damaged, and the chance of contraction greatly increased. Many smiths, who are merciless in paring the sides of the bars, which ought never to be touched by a knife, waste much time and patience in preserving the portion that projects beyond the surfice of the sole, which they had better have pared down nearly to a level with the sole, as it only impedes the removal of the dead horn from the corner of the sole at the heel, and would have been worn away, if the presence of the shoe had not prevented it.

The frog may be said to consist of three portions, viz., the horny frog, the sensitive frog, and a thick elastic eushion, which is interposed between the sensitive frog and the navicular joint, for the purpose of protecting this important little joint from injury: the portion, lowever, with which we are now more immediately concerned, as connected with the mechanical art of shoeing, is the horny firog.

No part of the foot shows the difference between good shoeing and bad so soon, or so palpably, as the frog. The frog of a foot that has been well shod for some time presents a full, plump appearance, with an even surface and a broad oval cleft, with a well-rlefined edge, not broken through at the back; whereas a frog, that has been long subjected to bad treatment, is shrunk and hard, with a ragged meven surface and a narrow cleft broken through at the back, and extending up between the bullss of the heels. The horn of the frog is thinner 
and of a closer and more delicate texture than the horn of the hoof; and is evidently intended not only to protect the parts immediately above it, but also to prevent the evaporation of the moisture which keeps these parts in a soft, yielding condition; but it cuts so easily, and looks so clean and trim when its surface is pared ofl; that very few smiths indeed can be prevailed on to leave it alone, and not even ent off the rags; nevertheless they had better do so, for those very r'ags which they think it desirable to remove were caused by paring off the surface of the horn at the last shoeing, whereby a part was lain bare that never was intended to be exposed to the action of the air, and which in consequence became dry and hard, and soon cracked, and the edges having curled ontwards formed the rags which are so offensive to the eye of the smith; and, if he should be tempted to remove them, he will again lay the foundation of other cracks and other rags, until at last the frog will have dwindled down by small degrees to half its original size. Now if, instear of persisting in this gradual work of destruction, he would only leave the frog alone, and never tonch it with a knife, the rags in due time would entirely disappear, and the frog become covered by a coating of newly secreted horn. 'The horn of the frog, when left to itself', is always undergoing a process of exfoliation and reproduction. 'The exfoliation for the most part occurs in small particles, resembling the dust which adheres to Turkey figs; but at other times the whole surface of the frog will exfoliate in a mass, leaving a smaller, but still perfect, frog beneath, corered with sound horn. 'The small particles of exfoliated horn may best be seen in the feet of horses shod with leather, where the artificial covering has prevented their escape; and so little is this natural process of exfoliation understood by horse-masters in general, that I have frequently had my attention gravely directed to the accumulation of these particles, as unmistakable evidence of the leather having rotted the frog.

The shoe should be neither too light, nor too narrow in the web: light shoes are apt to bend before they are half worn out, and narrowwebbed shoes expose the sole and frog to unnecessary injury from stones in the road. Every fore-shoe should be more or less seated on the foot-surface, to prevent it pressing on and bruising the sole; but a perfectly flat surface should be preserved around the edge of the foot-surface of the shoe from heel to heel for the crust to rest upon. The amount of seating to be employed must be determined by the description of foot to be shod; for instance, a broad foot, with a flat sole and weak horn, will require a wicle web, considerably seated, to prevent it coming in contact with the sole and bruising it; but a narrow foot, with an arched sole and strong horn, will require less width of web and less seating, otlerwise the dirt and grit of the road would become impacted between the shoe and the sole, and cause as much pressure and injury as the iron would have done.

The safest guide to the proper amount of seating is to apply the shoe to the foot, and observe whether there is room for a picker to pass freely between the shoe and the sole; if there should not be sufficient space for a free passage all round the shoe the seating must be increased ; and if there should be more than is necessary, it must be 
diminished. The smith, having carefully prepared the foot, and selected a shoe with a proper amount of seating for it, has next to cut off the heels, and fit the shoe to the foot; and he must always bear in mind that fitting the shoe to the foot does not mean fitting the foot to the shoe-an error that smiths are prone to fall into.

I have very frequently had occasion to remind a smith, that he was saving himself trouble at the expense of the horse by accommodating the foot to the shoe, instead of altering the shoe to the foot; and it must be confessed, that unless a smith is encouraged to take an interest in his work, by the owner of the loorse paying an occasional visit to the forge, and showing that he, too, is interested, it is very tempting to liim, when he finds the foot and the shoe do not come well

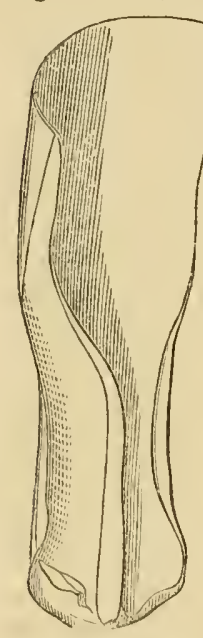

Fig. 1. together, to adopt the more expeditious and less troublesome course of substituting the knife and rasp for the hammer and anvil. Every forge is expected to be supplied with store shoes "turned in the rough," and if they were left longer in proportion to their width, and straighter at the quarters, with the heels wider apart than we usually find them, the labor of fitting the foot accurately would be greatly diminished, as we shall see when we come to consider that part of our subject. The first thing, however, that demands our attention is the mode of cutting off the heels to the required length; and for this purpose a curved chisel, as shown in Fig. 1 , is a more convenient tool than a straight one, and saves the smith much trouble in "filing "p" the shoe before he nails it to the foot; it removes the corners and rounds the points of the heels at once, and enables him to fit the heels of the shoe to the heels of the hoof with greater nicety than he can possibly do when they are cut off square. The best. manner of proceeding is to remove a small corner from the outer rim on each side, and a larger and longer portion from the inner rim, as shown by the dotted lines $\mathrm{A} \mathrm{B} \mathrm{C}$,

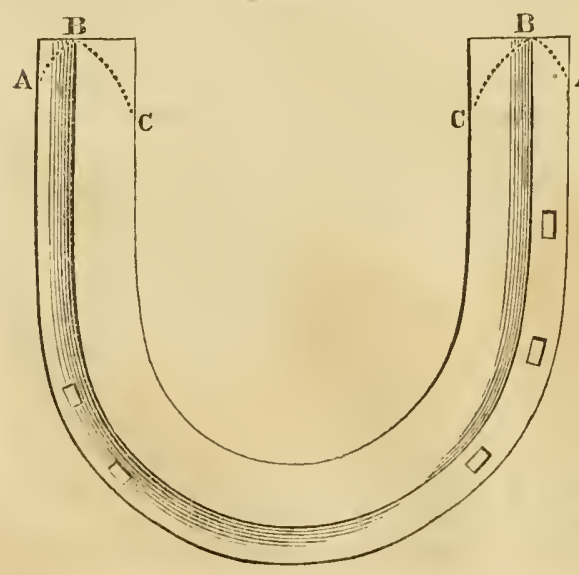

Fig. 2. in Fig. 2. By this mode of cutting off the heels A the outer rim of the shoe is lengthened, and the inner rim shortened, without diminishing the width of the web, as shown at A C, in Fig. 3. After the heels have been eut off, as directed above, the nailholes should be opened; and the best mode of doing it is to make them pass straight through the sloe, instead of inclining inwards in the direction of the centre of the loof; as is almost invariably 
clone, the effect of which is to convert a simple and safe operation into one of difficulty and danger, for the nails must first be driven with their points inclining inwards, and then outwards, until at last they emerge high up in the thinnest part of the crust, having split their way out in the direction of the filures of the horn, with a great probability of some portion of the shanks lying so elose to the sensitive lining of the hoof as to press upon it when the foot is in action and expands. Where the holes are thus made

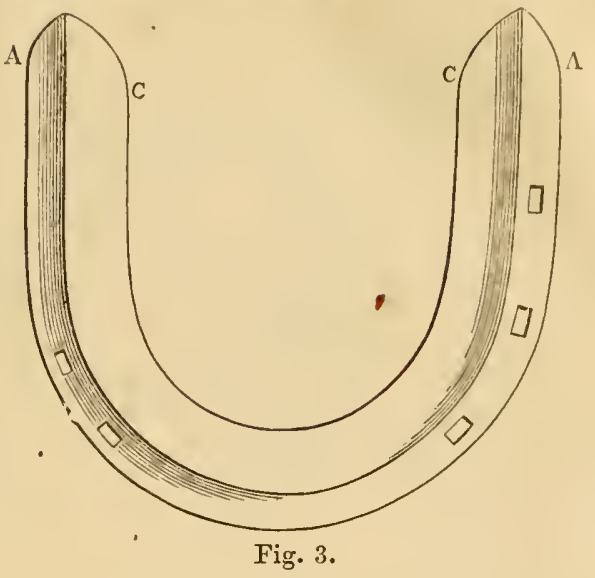
to incline inwards it requires considerable dexterity to drive the nails so as to steer clear of the many dangers that lie in the way. I do not allude to the graver natter of pricking the foot, as it is called, but to the thousand and one varying degrees of pressure from the shanks of the nails, causing constant uneasiness, or, it may be, pain in the foot. If the quick has been wounded the horse soon tells the tale, but if he is only uneasy from pressure, he bears it patiently, and it is never known to his master, although it is very frequently the unsuspected cause of broken knees.

We hear much about rolling stones in the road causing broken knees; a rolling stone is a very convenient scapegoat for a large amount of bad riding, bad driving, and bad shoeing; but, I take it, we should be much nearer the truth, in nine cases out of ten, if we attributed the misfortune to misplaced nails, driven through holes slanting inwards. When the nail-holes are made to pass straight through the substance of the iron, and the angle at which the hoof meets the shoe is considered, it will be self-evident that nails, driven straight through those holes, must cross the grain of the horn and come out low in the crust, presenting the strongest portion of the shank for a clench; and my experience tends to show, that nails so driven obtain a much firmer hold in consequence of their piercing the horn across the grain, than nails driven higher up the crust with the grain.

A few observations on the fuller, or groove in which the nail-holes are stamped, may not be out of place here, with a view to correct an error that almost all smiths fall into, of making their fullering-irons so fine and thin, that the grooves produced by them will not permit the heads of the nails to sink into them as they ought to do. They appear to forget that the safety of a half-worn-out shoe depends on the heads of the nails having sunk well into the groove, and fairly blocked the bottom of the holes. They are all impressed with the notion that a narrow fuller, with sharp well-defined edges, looks neat 
and indicates skilful workmanship; and perhaps it does look neater than a coarse, open groove, but it is attended with the great disadvantage of being much less useful. An open fuller atfords more space for the head of the nail, and prevents its becoming tied in the upper part of the groove before the lower portion has descended to the bottom of the hole, which invariably happens when the fuller is deep and narrow.

Horseshoeing at best is but a necessary evil, and cannot be elevated to the rank of an orramental art; smiths had better, therefore, confine their views to the utilitarian principle entirely, and thereby endeavor to make it as little hurtful to the horse, and as little inconvenient to his master, as they possibly can.

Having cut off the heels and opened the nail-holes, the next thing to be done is to turn up a clip at the toe preparatory to fitting the shoe to the foot, which latter operation should always be commenced at the front of the foot, and be gradually and carefully carried back to the quarters and heels. Fvery shoe should have a elip at the toe, to prevent the shoe being driven back on the foot and bending the nails in the crust; but I strongly object to the clip, which I often see turned up on the outside of a shoe, which is not only useless but destroys more horn than two or three nails would do.

No one doubts the fact of horses travelling safer and better in shoes a week or two old than they do in perfectly new ones; and this arises from the fact of their having worn away a portion of the iron at the toe, and thereby diminished the jar which the foot had previously received from the front of the toe coming in direct contact with the surface of the road. In order to relieve the horse from any unnecessary jar to the foot I always have the whole breadth of the toe of the shoe turned up, so as to raise the gromul-surfice of the shoe at the toe above the level of the ground, by which arrangement horses are found to trip less, and put their feet down with greater confidence. The plan of welding a lump of steel on to the toe of the shoe only makes bad worse; it increases the jar, is longer wearing away and causes the horse to trip more and for a greater length of time; whereas turning up the toe of the shoe obviates the evil at once, and makes the shoe last quite as long as the steel would liave done. All feet will not bear the same amount of elevation of the toe: strong feet will bear a good deal, but flat feet with weak horn will bear only a little; still that little should be imparted to the shoe. The old shoe, placed on a flat surface, will afford a very good guide to the amount of elevation to be given to the toe of the new shoe, provided the old one is not worn so much as to be thoroughly and entirely worn out.

A very convenient and handy tool for turning up the toe of a shoe may be made by welding a piece of bar-iron five inches long, one inch broad, and somewhat less than a quarter of an inch thick, crosswise on to each blade of a pair of smith's tongs. Any smith can manufacture such a tool for himself, and will find it very useful by enabling him to grasp both limbs of the shoe at the same time, and turn up the toe over the end of the anvil without twisting the shoe, which he could not do with common tongs; and he can easily restore the seat- 
ing at the toe by merely turning the shoe on the anvil. Fig. 4 will slow this tool in use. Having turned up the toe of the shoe and fitted it carefiully to the toc of the lioof, the smith must direct his attention to the quarters and heels, and whatever shape they may happen to take, that shape must be inplicitly followed by the shoe; whether the quarters be straight or curved, or the heels narrow or open, the shoe must follow the same shape; it is a grievous mistake

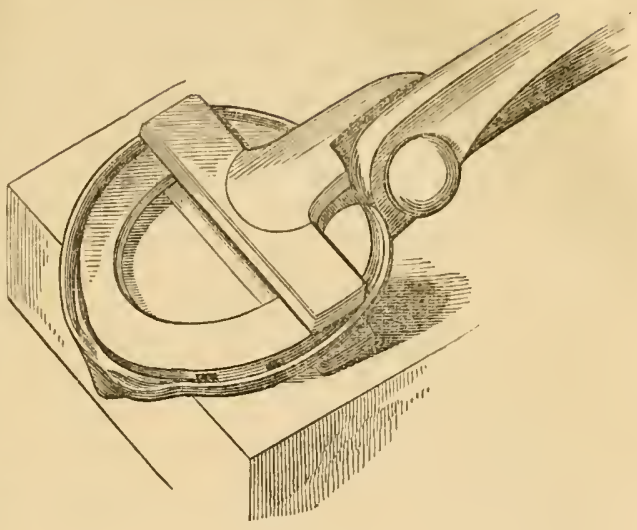

Fig. 4 to suppose, as too many persons do, that it is in the power of the smith to change the form of the foot by merely changing the form of the shoe: what are called open-heeled shoes will not make openheeled feet. The situation of the nails alone can alter the form of the foot, either by preventing or permitting the hoof to expand to the weight of the horse. If the shoe is nailed from heel to heel the hoof eannot expand, and the foot must become damaged; but if it be nailed, as I direct, with three nails on the outside and two on the inside, a foot, that has been already damaged by bad shoeing, may to a great extent be restored by thus permitting the foot to expand.

As a general rule, the first nail on the outside should be placed an inch and a half from the centre of the toe, the second in the middle of the quarter, and the third just behind the quarter; and on the inside, the first nail should be rather more than an inch from the centre of the toe, and the second about three-quarters of an inch behind it; by this arrangement the whole of the inner quarter and heel are left unfettered and free to expand. and any undue pressure on the sensitive parts of the foot, from the descent of the bones into the hoof, is avoided. Fitting the lieels will call for a little extra care at first, as it involves the abandonment of some deep-rooted prejudices and groundless fears. First, the prejudice in favor of square heels projecting beyond the hoof, koth behind and at the sides, must be yielded; and the fear lest the smallest portion of the shoe shonld happen to touch the frog must be given up, before anything like accurate fitting can be obtained. The edge of the shoe must be made to correspond with the edge of the hoof all round, from heel to heel, and to do this effectually, and to keep the web of the shoe as wide at the heels as it is at the toe, the heels nust be brought in until they very nearly touch the frog. I would not have them bear on the frog, but $I$ would rather see them touch it than be able to lay my finger between the firog and the shoe.

There are many advantages attending the bringing in of the heels, and not one single disadvantage to set against them. In the first place, it removes all the points and projections by which stiff ground is enabled to pull off the shoe; in the next place, it affords a good, 
firm, flat surface for the heels of the hoof to rest upon, and, by bringing the sides of the shoe nearer together, the navicular joint, which lies in the hoof above the frog and about an inch from its point, is saved from many an unlucky jar from a stone in the road, by the shoe receiving it instead of the frog. 'The shoe must not only fit the edge of the crust, but the whole of the crust must have an even bearing on the shoe, and this can only be effected by making the shoe hot enough to scorch the horn, and applying it to the foot. The quantity of horn to be thus destroyed, when the foot and shoe have both been made as level as the smith can make them, is very inconsiderable, and the heat so applied can do no harm. I would not have the shoe burnt into its place on the foot withont previous preparation, as is very often done to save a little trouble, but I wonld have the hot shoe applied so as to insure a close fit all round. $\Lambda$ thin, weak hoof will not bear as much heat, without inconvenience to the lorse, as a strong one; but as a close fit is of even more importance to a weak hoof than it is to a strong one, it is essential that the shoe be applied to it hot enough to scorch the projecting portions of horn, in order that they may be seen, and removed by a rasp.

It is a very good plan, in fitting the shoe to the inner quarter and heel, to keep the rim of the ground-surface of the web within the rim of the foot-surface, somewhat after the fashion of the shoe in common use for preventing cutting; it enables the horse to withdraw his shoe from stiff ground without the chance of leaving it behind him, which he will inevitably do if any portion of the shoe is permitted to project beyond the hoof. When the shoe has been carefully fitted to the foot it must be cooled and "back-holed;" that is, the nail-holes must be opened on the foot-surface of the shoe; and in doing this care must be taken to break down the outer edge of all the holes, so that the nail may pass straight throngh the shoe withont any inclination inwards, and the openings should be made large and free, to prevent the shank of the nail becoming tied in the lole before the head has been driven fairly home.

The shoe has.then to be "filed up" preparatory to being nailed to

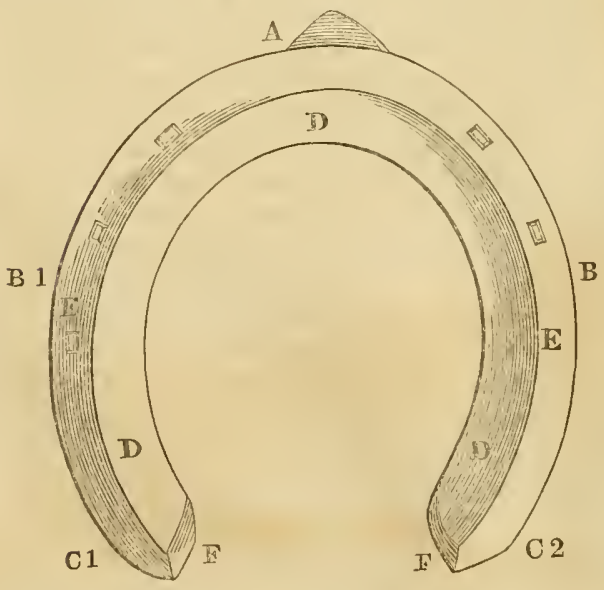

Fig. 5. the foot; and I may liere observe, that much time and labor are generally wasted in polishing portions of the shoe which might very well be left alone; all that is really necessary is to round off B 2 the sharp edges, remore any "burs" that may project from the surface, and file the foot-surface of the heels, as shown at F, in Fig. $\tilde{~}$. Fig. 5 shows the foot-surface of a near fore-shoe; $A$, the clip at the toe; $B$, the outer quarter ; B 2, 
the inner quarter; C 1, the outer heel; C 2, the inner heel; D, the scating; $\mathrm{l}$, an even flat surface from lieel to hecl for the crust to bear upon, and in which the nail-holes must be placed. 'They must never be permitted to encroach on the seating, but be always confined to this flat surface; $F$, the ends of the heels filed away in a direction upwards and outwards, the object being to prevent pressure on the frog without diminishing the width of the web on the ground-surface of the shoe. Fig. 6, the ground-surface of the same shoe. A, the toe turned up out of the line of wcar; B 1, the outer quarter; B 2, the inner quarter; $\mathrm{C}$ 1 and $\mathrm{C} 2$, the heels; with $\mathrm{D}$, the web as wide as at any other portion of the shoe; E, the fuller. It will be observed that the inner quarter of the shoe, marked $\mathrm{B} 2$ in each of the figures, is considerably straighter than the outer quarter marked B 1 , which is the natural shape of a well-formed foot: the inner quarte: is not only straighter. and more upright than the outer quarter, but

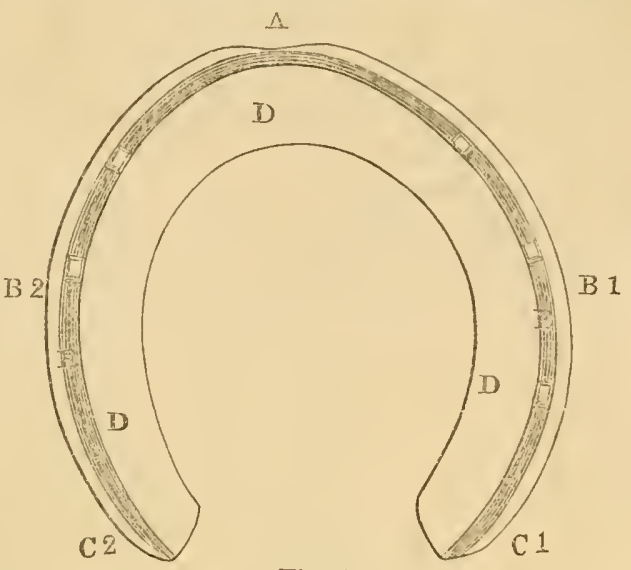

Fig. 6. the crust is thimner and more elastic, and consequently expands in a greater degree to the horse's weight; but when we talk of the hoof being elastic and the foot expanding, we would by no means have it inferred that they bear any relation to the elasticity or expansion of India-rubber; if they did, the bones of the foot would be thrust through the hoof during violent action, or in a down leap. The elasticity and expansion are small in degree, scarcely exceeding the eighth of an inch in the feet of most hor'ses, that have been several times shod, but they are most important in their consequences, by affording exactly the anount of enlargement of the cavity necessary for the descent of the bones of the foot, without squeezing the sensitive parts which line the hoof.

Before I say anything about nailing the shoe to the foot, I liave a few observations to offer on the nails usually employed for the purpose, which are very defective in form and ill-contrived for obtaining a firm and lasting hold, although I am bound to confess that I hare lately seen a manifest improvement in some of the nails of commerce; but the general run of them are made with heads so short, square and broad at the top, and so small and narrow at the bottom, with shanks springing suddenly from them, that the upper part becomes tied in the fuller before the lower part has reached the bottom of the hole, and the consequence is, that the bottom of the hole is occupied by the shank alone, and before the shoe is worn out the 
head of the nail is gone, and little more than a brad remains to retain the shoe.

The smiths who shoe my horses make their own nails, and I recommend others to do the like, at least for the better class of horses ; it gives them an opportunity of choosing their rods, making their wails of a better shape, and cooling them more gradually than the wholesale manufacturers do, whereby they are rendered tougher and less liable to break. The head of the nail should be oblong on the top, straight-sided at the upper part, and die away gradually into the shank with a broadish shoulder, to fill the opening made by "backholeing" the shoe; hence the necessity for these openings being larger and freer than they are usually made. A nail so formed will always retain the semblance of a head, and can never be reduced to a mere headless brad. The shank should be less taper, and the point less elongated, than those of the nails in common use. The shorter point and broader shank supply a firmer and better clench.

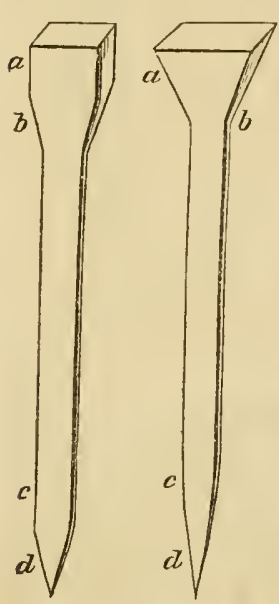

Fig. 7. Fig. 7 represents the two nails I lave been endeavoring to describe; but a comparison of the letters attached to each will perhaps convey more clearly what I mean than my words may have done. When the nail-holes are in the right places and pass straight through the shoe, and the shoe has been properly fitted to the foot, the difficulty of nailing it on is reduced to nothing, and might almost be handed over to a carpenter to do with as much confidence as to a smith; the nails have only to be driven straight, and they must pass through the shoe, across the substance of the horn, avoid the sensitive parts altogether, and come out in their right places, presenting the strongest portion of the shank for a clench, instead of the thin narrow point; the smith has then only to twist off the projecting portion of the mails, cut a notch in the hoof to receive the turned-down elench, and bury it with his hammer in the notch so formed, and not touch it again with a rasp; in fact, a rasp should on no account whatever be applied to the surface of the hoof above the clenches; it tears and destroys nature's covering, designed to keep the horn moist and tough, and renders it dry and brittle.

I shall, no doubt, astonish some persons when I assert that nearly all the evils incident to horseshoeing are attributable to the affectation and dandyism of the smith, who is not contented to follow a necessary and useful art, simple in its mechanical parts, but calling for the exercise of some judgment in its application, but he must import into it dangerous difficulties and mischievous ornament: for instance, he assumes that a deep narrow fuller, with small nail-holes inclining inwards, and still smaller openings on the foot surface of the shoe, present a neat, trim appearance, and slow that he is master of his art; knowing full well, that nothing but long practice could enable any one to navigate a nail safely through a channel beset by so many 
dangers; but he entirely overlooks the fact that the power to do so has nothing to recommend it but the danger and risk attending the performance. Again, he imagines, that a hoof carefully rasped all over imparts an air of finish to his work, of which he feels proud, forgetting altogether that he has removed a most important covering from the houf, for which no amount of ornamental finish can compensate.

I am anxions again to impress on smiths and their employers that horseshoeing is at best but a necessary evil, and that any attempt to raise it to the rank of an ornamental art must be attended with damage to the horse and inconvenience to its owner. My sole object is to render it as safe, simple, and useful as possible ; to divest it of all difficult and dandy erotchets in its application, and reduce it to one principle, to be carried out in the shoeing of all sorts of horses, at all sorts of work.

This principle, which admits of no variation, may be summed up as follows: the shoe must fit the foot from heel to heel, whatever the shape of the foot may be, and the crust must have an equable bearing on the shoe all round; the toe of the shoe must have a clip in the centre, and, when the foot will bear it, the toe must be elevated from the ground; the nail-holes must be so placed as not to encroach on the inner quarter, but leave the inner quarter and heel free to expand, and they must pass straight through the shoe; the frog must never be touched by a knife, or the surface of the hoof by a rasp. The detail may fairly be left to the judgment of the smith, who will be able to determine the description of shoe best caleulated to meet the requirements of the foot that he lias to deal with; he will have to consider whether it is strong and upright, or weak and flat, and be guided by those circumstances as to the substance, width of web, and amount of seating the shoe must possess, and also the degree of elevation of the toe the foot will bear. These are matters of detail infringing no part of the principle, and may and ought to be left to the experience and judgment of the smith. Fig. 8 represents the ground surface of a near fore foot,

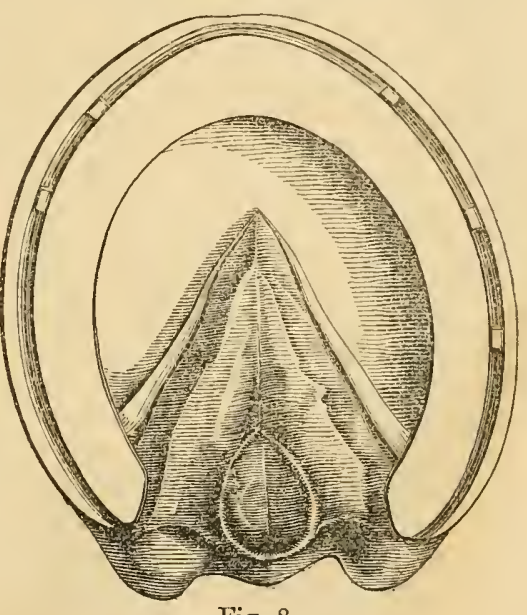

Fig. 8. shod as it ought to be, and Fig. 9 represents the same foot, with the shoe rendered transparent, showing the portions of the foot that are covered and protected by it, $\mathbf{A}$ the crust, $\mathrm{B}$ the bars, and $\mathrm{C}$ the heels; it will be seen, moreover, how bringing in the heels diminishes the opening of the shoe and lessens the chance of stones in the 
road brinising the frog; one side or other of the shoe would alight upon them and save the frog. I may observe in passing, that corns have never failed to disappear under this mode of shoeing; they are

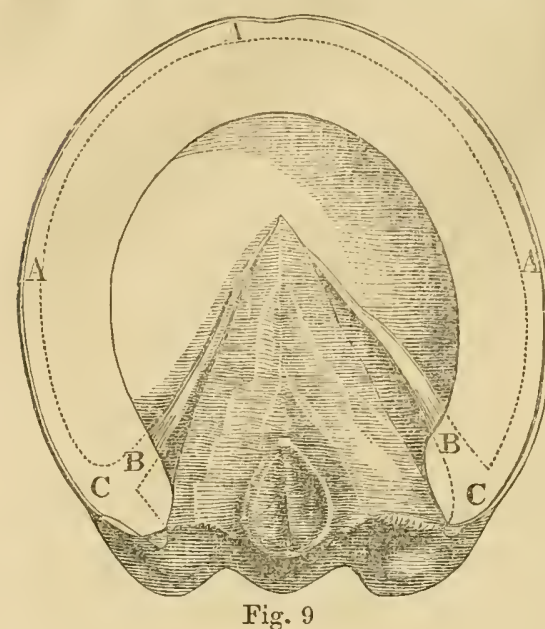

Fig. 9 always the consequence of bad shoeing, and good shoeing always removes them. I could not keep a corn in my stable, if I desired it ever so much, unless I altered my plan of shoeing. A large number of flat-footed horses cannot go safely at any time without some protection over the sole, and all hor'ses would be benefited by it when the roads are strewed with loose stones; but it is a mistake to suppose that leather, or any substitute for it, inserted between the shoe and foot, calls for a greater amount of fastening than five nails; they will retain a shoe, with leather under it, as firmly as if the leather were not there: all that is required is, to make the leather fit the shoe as accurately as I desire the shoe to fit the foot, and that no projecting portions be left either behind or at the sides of the heels, and instead of the leather being cut square at the heels, I would have it slightly arched inwards from heel to heel. It is necessary, however, to prepare the foot, before the leatiner is put on, and the best way of doing it is to smear the whole lower surface of the foot and fiog with common tar; gas-tar must be especially avoided, as it dries and hardens the horn, instead of keeping it moist and promoting its growth, as common tal does; then the hollow on each side between the frog and the crust, from the point of the frog back to the heels, should be filled with oakum dipped in tar, and pressed down until the mass rises somewhat abore the level of the frog on each side, and gives it the appearance of being sunk in a hollow. A small portion of oakum may be spread over the sole in front of the frog, but none must be put on the frog itself excepting the bit in the cleft, which is necessary to prevent dirt working in from behind. The best way of dealing with this bit is to pull some oakum out straight, twist it once or twice, fold it in the centre, then dip it in tar and press it into the cleft, and carry the straggling ends across the frog, to mix with the mass on the side of it. Oakum is a much better material for stopping the feet than tow.

The usual mode of stopping the feet is to take a large wad of tow and spread it over the whole of the sole and firog in one mass, which is most objectionable, inasmuch as it causes a constant pressure on the frog, which is just what the stopping, to be at all useful, 
should prevent. Fig. 10 shows the stopping, properly placed in the foot, and Fig. 11 shows the apppearance the sanc foot wonth present when properly shod with leather. Just as I had proceeded thus far with my subject, I received a letter from a gentleman in the north of Deron, containing the following aneclote, and as it bears on the matter I lave in hand, I will at once record it. He appears to be a zealous advocate for the system of shoeing I have recommender, which I gather from his letters, for I have not the pleasure of his acquaintance. He tells me that a short time ago he sent his bailiff to a sale some ten miles off, and directed him to take a very hot pony he possesses, which had never been previously used excepting in the plough : this pony was shod with only four nails in each fore shoe, and he cast one of them by the way. The bailiff took him to the nearest forge, and told the smith to put on another, and at the same time called his attention to the way in which his shoes were made and put on. His reply was, "I never saw a horse shod like this; it will never do for this conntry; no wonder lie cast his shoe: but I'll put one on my

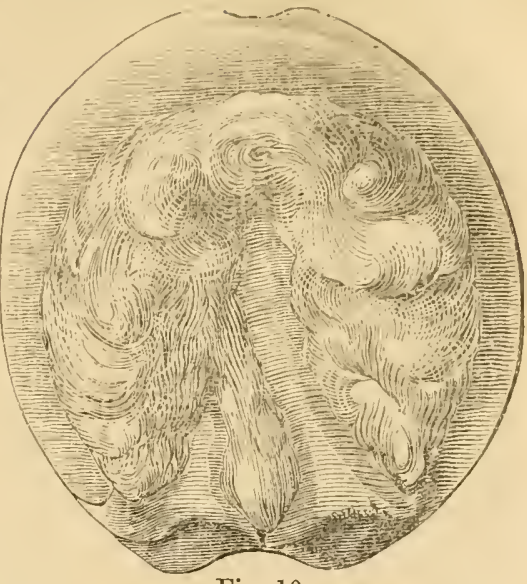

Fig. 10.

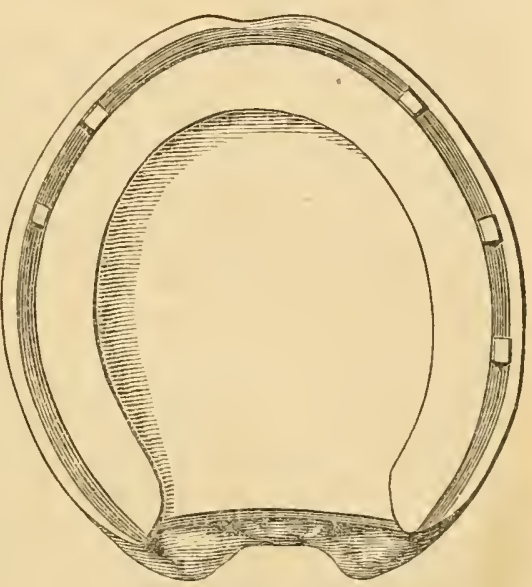

Fig. 11.

way, and I warrant he won't throw that." Accordingly the shoe was put on, nailed inside and out with eight nails, and two or three days afterwards the pony went to plough again in some stiffish clay for an hour or two, and when his work was finished it was found that he had left his new shoe behind lim somewhere in the elaty, but the other shoe, with four nails in it, was safe on his foot.

The fact is, that a larger number than five nails are never required excepting for the purpose of connteracting defective fitting, and in this case the fitting was clearly so bad that eren eight nails could not hold it, although placed in the small shoe of a pony. I may mention here that a few days ago my grom picked up a shoe in the road with nine nails sticking in it, and I was struck with his obserration on 
finding it. He said, "if this had been one of our shoes, sir, with only three nails in it, there would have been a pretty talk about it; but as there are nine, no one will say anything about it:" and I have no doubt of the correctness of his conclusion, for human nature is prone to be very tender over the misfortunes of long-cherished prejudices, but merciless in its visitations on the failure of any attempt to correct them.

The hind foot is differently formed from the fore foot, and requires to be differently shod; nevertheless, the same principle of fitting the shoe to the foot, whatever its shape may be, bringing in the heels close to the frog and placing the nail-holes so as to permit the inner quarter and heel to expand, applies with equal force to the hind as it does to the fore shoes. One ot the great mistakes smiths fall into in shoeing hind feet is squaring the toe, and placing a clip on each side of it, with a view, as they say, of preventing the horse striking the toe of his hind shoe against the heel of his fore shoe, and producing the disagreeable sound, called "forging;" but as a horse never does forge with his toe, the plan of squaring it and the reason assigned for it equally fail in their object, and, like many other fallacies connected with the art of horseshoeing, produce the rery results they were intended to obviate.

A horse forges by striking the outer rim of each side of the hind sloe, just where it turns backward, against the inner rim of the fore shoe, just behind the quarters; therefore the broader the toe of the hind shoe is made by the squaring and the clips, the more likely the horse is to strike it against the fore shoe. It happens in this way : the horse fails to carry his fore foot forward quickly enough to get it out of the way of the hind foot, and the toe of the hind shoe is thrust into the opening of the still held up fore shoe, and the outer edge of the hind shoe strikes against the inner rim of the fore shoe and produces the sound. I have entirely cured several horses of forging by merely causing the corners of the artificially-squared toe to be removed and the toe restored to its natural form.

The best mode of treating the toe of the hind shoe of all horses is to make it rounding and rather pointed, and to turn up a small stout clip in the centre: the toe should be tolerably thick, as the wear is always great at this part of the shoe, and the back edge should be rounded .with a file, particularly for horses at all likely to be put to fast work; it prevents the chance of "overreach," which, like forging, is often erroneously attributed to the front of the toe, but is invariably caused by the back edge, which, in a halt-worn-out shoe becomes as sharp as a razor. 'The accident is very properly named, for the horse really overreaches the fore foot with the hind foot, and the back edge of the toe of the hind shoe in its return passage to the ground strikes the soft part of the heel of the fore foot, and often produces a wound that is very troublesome and difficult to heal.

The only other portions of the hind shoe which require special attention are the heels, and in dealing with them we must depart widely firom the principle I have hitherto advocated of following nature as closely as possible. We are compelled to have recourse to art, not, however with a view of assisting, much less with a view of 
improving, nature's contrivances, but for the sole purpose of counteracting what, it must be confessed, is to a large extent a necessary interference on the part of man. Nature made horses with flat heels, but she put no sharp bits in their mouths; she left them free to choose their own time for stopping and their own mode of doing it; but as soon as they are subjected to the control of man, his heavy hand and sharp bit pull them up without warning, and without the smallest reference to the position they may chance to be in at the time, or indeed without reference to anything but his own sudden impulse. We must therefore do all we can to guard the poor horse against the numberless strains und injurics incident to his changed condition, and the best morle of effecting it is to raise the heels of the shoe, and keep the natural heels as far from the ground as is practicable without throwing the foot too much on the toe.

The plan I have adopted for many years past is to have the heels forged longer and deeper than is commonly done, and when the ragged ends have been cut off, the heels are made red hot, and the shoe placed in the vise with the heels upwards and projecting; the smith then hammers them down, to shorten and condense them, until the mass is reduced to abont an inch and a half in length; he then removes the shoe from the vise and makes the top, bottom, and sides of the heels flat on the anvil, preparatory to fitting the shoe to the foot, taking eare that both heels are of an equal height. This plan affords a larger and more even surface of support than mere calkins would do, and is better for fast work ; but calkins are very useful for heary draught, provided they are made of an equal length at each heel. Nothing is more distressing to a horse than working in shoes that bear unevenly on the ground, twisting and straining his joints at every step he takes.

Some horses have a habit of striking the foot or shoe of one side against the fetlock joint of the other side either with their fore or hind feet, and various devices have been at different times suggested as a remedy for the evil; but as each horse has his own mode of doing it, much difficulty is often experienced in hitting upon the right one. I have frequently solved the difficulty by placing a boot, or piece of cloth covered with damp pipe-clay, over the injured part, and then causing the horse to be trotted along the road, and he generally returns with some of the pipe-clay adhering to the offending portion of the opposite foot or shoe, as the case may be, pointing out pretty clearly the part to be lessened or removed. The adoption of this simple plan has saved many a horse from months of torture arising from ill-contrived shoes and misapplied remedies.

As a general rule, hor'ses' shoes should be removed' once between each fresh shoeing; but this, like all general rules, admits of exceptions, for if a horse wears out his shoes in less time than a month, they had better not be remored, or if he has a weak, brittle hoof, and does not carry his shoes longer than five or six weeks, they had better remain untouched, as such feet grow horn very slowly, and are rather injured than benefited by frequent removal of the shoes; but a horse with strong feet, who carries his shoes over a month, should 
have them remored and refitted at the end of a fortnight or three weeks, dependent on the time his shoes are likely to last.

The treatment, or I might almost call it the ill-treatment, that horses' feet receive in the stable requires a good deal of revision, and might very well commence with the all but universal custom of washing the feet and legs with cold water the moment the horses return to the stable from their work, when they are often heated, tired, and exhausted. Nothing can be more injudicious than subjecting them to the sudden chill, caused by a liberal application of cold water to their legs and fect at such a time, and then leaving them to dry as best they can. The amount of cold produced during the process of evaporation is so great, that the poor beasts remain in a state of chilled wretchedness for many hours before they become thoroughly warm again. If their legs and feet must be washed as soon as they return from their work, let it be done with water that is quite hot, and let them be rubbed dry immediately; they will then feel warm and comfortable, instead of being cold and miserable; but as many stables are not provided with hot water at command, the best plan is not to wash them at all when they first come in, but merely to pick out the feet, clean off the dirt, and leave them for several hours, until the circulation has recovered itself and subsided into a natural state, or even until the following morning, when they may be safely washed with cold water, and the delay will do no liarm.

Horses' feet are generally kept too dry in the stable; they all require moisture, and the best way of applying it is to surround the hoof by a wet swab, and keep it on for a few hours during the early part of the day, before the horse has been to work, but it must never be put on after his return from work. The feet should be stopped at night, and the best thing to do it with is fresh cow-dung, without any admixture of clay; when clay is added, the heat of the foot dries it, and the stopping becomes hard and does the foot more harm than good. Many persons, to save themselves a little trouble, substitute horse-dung for cow-dung; but they will do well to forego the whole of the trouble, and not stop the foot at all, rather than use horsedung for the purpose.

It is a very good plan to smear the hoofs, sole, and frog all over with some emolient dressing every morning, as soon as the horse has been cleaned and got ready for the day; it need not interfere with the use of the wet swabs, which may with advantage be placed over it. I have used the following preparation for many years in $\mathrm{my}$ stable, and have found it to be very efficient in preserving the natural covering of the hoof in a good healthy state, and, as a necessary consequence, the horn beneath it elastic and tough:-To a pound and a half of lard add a quarter of a pound of beeswax, a quarter of a pound of common tar, and a quarter of a pound of honey; melt the lard and beeswax together, and then stir in the tar and honey: they require to be stirred for some little time, until the mass begins to set. I am informed that the addition of two or three ounces of glycerine will prevent the mass becoming too hard, and I have no doubt, from the peculiar oily properties of glycerine and the numerous purposes for which I find it is used in surgery, that it would prove a val- 
uable addition to the hoof-dressing. What is required is some covering that shall prevent the escape of the natural moisture of the hoof, and at the same time be emolient, adhesive, not too fluid, and free from any irritant.

Various causes have combined during the last few years to enhance the value of horses of every description, and it has become incumbent on every one, whose attention may have been particularly called to the subject, to communicate any information his experience and eareful observation has supplied him with, and which he believes may be of use to his neighbors, by arousing them from the state of apathy into which many of them have permitted themselves to fall concerning a matter of so much importance to them commereially and personally as the soundness of their horses' feet.

Dixfield, December, 18557. 



\title{
[NEWT SERIIS.]
}

\section{A \\ PR I Z E E S A Y \\ ox \\ FAIR S.}

\author{
BY \\ A L L E W. DODGE, \\ OF HAMILTON, LASS.
}

B O T O N : 1858.

J, H. EASTBURN'S PRESS. 



\section{E S S A Y.}

In offering its prize for the best essay on the advantages to be derived from establishing regular fairs or market-days throughout the State, for the sale and exehange of agricultural produets, it is presumed that the Society did not mean to consider the question as settled in favor of such fairs; but wished rather to clicit inquiry into their merits as compared with the prevailing modes of disposing of the products of the farm; and if, upon a careful and candid considcration of the question, it should be found that there were suffieient and weighty reasons for the establishing of such fairs, that then some praetieal plan should be proposed for this purpose.

These fuirs or market-days, which in fact are nothing more than a periodical coneourse of people at a stated place for selling and buying agricultural commodities and for hiring laborers, have long been in successful operation in Great Britain. To the farmers there they are of great importance, constituting their chief, or perhaps their only, opportunities of effecting profitable sales or purchases of stoek. The different breeds of neat-stock, of horses, of sheep and of swine, are exposed to sale, often in large numbers and of great excellenee, at the local fairs in the quarter where they are raised; and they attract to them dealer's from a distance, with the certainty that they ean find just the description of animals they are in want of. This, with the loeal attendance, usually ensures a brisk business. And so great is the convenience of a market-day considered to be to the neighborhood in which it is held, that new fairs are constantly springing up, the only limitation to their number being the amount of business which may be controlled by them.

Besides live-stoek, fruit, vegetables and grains find purchasers at these finirs, and they are offered for sale either in bulk or by sample, the latter being the more usual way of disposing of large quantities of any commodity. Most of these fairs, too, have a well-known and speeifie charaeter, and are noted, some for the superior quality of one kind of stock or of produce, and others for that of another kind. And they often receive their name from the predominant artiele exposed to sale, as, for example, a fair at which large quantities of eherries are presented, is called the Cherry Fair, and one of which sheep is the characteristie feature is ealled a Sheep Fair.

But in this country, or at least in New England, we have nothing answering to these fairs or market-days. The nearest approach to them are the eattle markets established in the immediate vicinity of our largest cities, and mainly for the supply of the meat for their consumption, as those held weekly at Brighton and Cambridge, in our own Commonwealth, and which are the only markets of any extent for the sale of live-stock, within her borders. These, however, 
differ in some important particulars from the fairs proposed for consideration. They are exelusively for the sale and purchase of livestock, and that stock is mostly brought from a distance, sometimes even from the far West. They afford a good opportunity for farmers in the surrounding country to purchase such animals as they stand in need of, and they are resorted to very generally by them for this object. But they are not intended to encourage the sale of stock by these farmers, for the very obvious reason that but little or no stock is raised by them. They are also very inconreniently located, being at one extremity of the State, and therefore can be attended by the larger part of the farming population only at great expense.

What, then, would be some of the benefits of regular fairs or marketdays, established throughout the State, for the sale and exchange of agricultural products-benefits that might reasonably be expected from them? In the first place, they would offer to every enterprising farmer in their neighborhood a home market, or a market near at hand and easy of access. Studded all over as Massachusetts isespecially on her eastern borders-with cities and large towns and manufacturing villages, it might be thought that the farmers are amply supplied with good markets and at their very doors. To some extent this is indeed true, but it is equally true that very many farmers - a majority perhaps-are obliged to travel eight or twelve miles and sometimes more, in order to reach their nearest market town. The loss of time in thus travelling to and from market, and the wear and tear of horse and vehicle, are no inconsiderable items of expense to the farmer who is placed in this unfavorable position in regard to markets. Suppose that he follows the market weekly for two thirds of the year, there are then thirty-five days to be deducted from the working-days of the year, and if in the fall he goes to market two or more times in a week, the number would be increased fully to fifty days, including the occasional days in winter devoted to this object.

But the establishing of regular market-days in towns near to these farmers, would prevent very materially this heavy loss of time and the expense, to which they are now subjected. If there were twelve such market-days in a year, that is, monthly markets, where they would be sure of finding purchasers, they would save the difference between twelve and fifty days of time, which they then would have to spend on the farm in increasing its productions, besides making a corresponding saving in the service of horse and wagon. This saving to the farmer may perhaps be more sensibly measured and appreciated, by considering what has been so justly stated by Henry C. Carey, in the Plough, Loom and Anvil, for September, 1851, in respect of labor.

"The first of all the taxes to be paid by labor is that of transportation. It takes precedence even of the clains of government, for the man who has labor to sell or exchange must take it to the place at which it can be sold. If the market be so far distant that it will occupy so large a portion of his time in going to and returning from his work, as to leave him insulficient to purchase food enough to preserve life, he will perish of starvation. If it be somewhat less distant, 
he may obtain a small amount of food. If brought near, he may be well fed. Still nearer, he may be well fed and poorly clothed. Brought to his door, so as to make a market for all his time, he will be well fed, well clothed, well housed, and he will be able to feed, clothe, lorlge, and educate his children."

What is here said of labor applies with equal force to the products of labor, the nearer the market the more perfect is the power to exchange them and the higher is their price. Trite as is Franklin's proverb, it is not the less true, that "time is money." And yet our New England farmers, trained as they are to habits of thrift and economy in other particulars, and certainly not wanting in any of the essential qualifications for trade, seem, too many of them, in this important matter of marketing their produce, to set scarcely any value at all upon time. But if their time be worth to them any thing at all, if it will yield any return when skilfully employed, it surely ought not to be thus misspent, not to say squandered in a reckless and shameful manner.

In the second place, market-days, by bringing the purchaser to the producer, or rather by creating a half-way place and common ground of meeting for business, instead of the producer being obliged, as is now most frequently the case, to go to the purchaser with his commodities, would tend to make better prices and quicker and more certain sales for them. As at present managed, the farmer takes or sends to his nearest market town such things as he has to dispose of, and unless he has a regular set of eustomers, he may be put to much trouble and inconvenience to find a purchaser, and must then often sell to a disadvantage. If, on the other hand, there is collected a large number of buyers at a stated time and place, and there are assembled such products of the farm as all are desirous of purchasing, it is clear that there will be more or less competition, and that sales will be readily effected at remunerating prices.

The tendency of trade in this comntry is to centralization. The large manufacturers of cotton and woolen goods and of boots and shoes, instead of selling at their factories, have their places for making sales in the metropolis. And where the manufacturer and the salesman are united in the same person, it makes but little difference whether the factory and the shop are in one and the same place or at a distance from each other. But where the manufacturer sells his goods to the merchant, who buys to sell again, - as is the case with boots and shoes-then it makes oftentimes all the difference to the manufacturer, of a living profit by the sale of his goods, or no profit at all, whether the purchaser comes to the manufacturer, or the manufacturer goes to the purchaser. The scripture adage- "It is naught says the buyer,"-will operate in the former case with unrestricted vigor, while in the latter it will fail of its object to depreciate the price of that which it is known is wanted by the purchaser.

In the third place, no small advantage would accrue to the farmer by the establishing of regular market-days, from their tendency to equalize the prices of agricultural products. At present, prices are left to depend too much upon caprice and accident, and but little difference is made between different qualities of the same article. 
An inferior article often brings as much as, or more than, a superior one; so that the sale of agricultural products resembles more a lottery than a fair and equable traffic. "What luck to day?" is the usual interrogatory put to the farmer on his return from market, meaning thereby not whether a sale was effected of his produce, but at what rates. And as a consequence of this uncertainty in prices, there is but little inducement to prepare for the market any commodity-such as butter or cheese-of a superior quality, when it is well understood that as a matter of dollars and cents, an inferior one, requiring less time and labor in its production, will pay much better. The advantage of an open market where products of a similar kind are exposed to sale side by side, is that a standard of prices is readily fixed, each takes its place according to its merit and commands the price to which it is fairly entitler. And this advantage enures to the buyer as well as the seller, and gives character and stimulus to the market.

In the fourth place, in connection with this benefit and closely allied to it, is the healthy emulation which is excited by bringing different specimens of the same products into comparison with one another. Competition of the right kind at once springs up-a competition to excel in the quality of the article produced and not merely in the price obtained for it. 'The man who has been contented to produce an ordinary article, because he has generally obtained a good price for it, or because he has never seen any thing superior to it, is stimulated by the success of his neighbor, both as to the quality and price of his products, to produce a better; whilst the other to maintain his advantage and to avoid the mortification of being surpassed by his competitor, increases his skill and pains-taking. It is thus that progress in all the arts is effected, aud it is only thus that progress in the important art of agriculture is to be achiered.

Besides this beneficial result, these fairs would tend to diffuse information, just as our cattle shows do, by promoting intercourse between men engaged in a common pursuit, and bringing their minds into contact on subjects connected with it. Enquiry into the different processes by which results are obtained in the various branches of husbandry is thus excited, and the why and the wherefore of each are freely discussed. It cannot be otherwise than that the farmer must return from these fitirs a wiser man, or if he thought that all wisdom would die with him, that this conceit must be rubbed out of him by the friction to which he has there been subjected. It often happens, for want of this intercourse among farmers, this interchange of opinions and mutual comparison of skill and intelligence, that individuals exhibit an overweening pride in respect of certain processes or products, which is not warranted by facts and is simply ridiculous. One of these self-sufficient farmers, who had always in his own estimation the best of every thing, was heard to utter the boast, when speaking of the prospects for a hay crop, "that he should have had the best in the county, if his hay-seed had only caught !"

There is no denying that as a class our farmers are set in their opinions, whether well or ill founded, and this arises as much from their living comparatively by themselves, as from that independence 
of character, which springs from their occupation. The commercial intercourse of these fairs would supply just what is wanting to many of our farmers, it would liberalize their views and enlarge the sphere of their observation, and as a necessary consequence agricultural knowledge would be advanced. Indeed these fairs would become a school for the young farmer, and for all farmers who were not too old to learn. The various breeds of stock could here be learned, their points noted, their peculiar marks of excellence ascertained and a vast amount of experience and information in regard to them gained. Trained in such a school, our farmers would become much better judges than they now are, of farm stock. And will any one pretend that it is not rital to the interests of the farmer to be able to judge of a good cow or of a good pair of working cattle, so as to be seldom disappointed in making his purchases? Should he not here as in other transactions be able to think for himself, and if need be to give a reason for his opinion? Will he not at least have more self-respect and command better the respect of others, than by a blind and haphazard way of doing his business?

The farmer needs to be well versed in the knowledge of buying and selling, and this knowledge can be acquired only by observation and the exercise of his own faculties. Many farmers fail herethey raise good crops and they harrest them in good order-but when they come to dispose of them they are at fault; they are either too early or too late in making sales, and liave usually the worst end of the bargain. Now why is this? Mainly for want of practical experience in trade. The narrow round of their customers gives no opportunity for them to learn, and they go through life with but little skill in this the financial department of husbandry. The establishing of market-days, by collecting large numbers of buyers at one place, and by the competion excited thereby, would give to the farmer more tact in trading than it is possible for him now to acquire.

In the last place, these market-days or fairs would tend to concentrate New England farming upon fewer products, by making near and certain markets for them. As it is now, our farm products are too varied-we raise a little of every thing, and not enough of any one thing to make it profitable, from the expense of disposing of them. Of many articles raised on the farm, the little surplus over what is wanted for home consumption is taken to market. As a consequence, sales are uncertain and the proceeds come in by driblets. And there is at present little inducement to go largely into any one production. But create a fixed market near at hand, and our farming would at once shape itself accordingly. One farmer wonld take to neat stock, another to sheep and another to pigs, and they would all aim to have the best breeds, and the best animals to take to the market. Quick sales, too, would be had for them, if it was known, as it would be, when and where they were to be offered for sale. At the same market the farmer could buy what he is now forced to raise or to purchase at great disadvantage. The farmer who went into stock raising, would not be likely to raise all other farm products, as he could find them at hand, on market-day, much cheaper. There would thus be a division of agricultural labor that would be for the common 
good. Few farmers in this State think of raising their own wheat, as they can buy flour much cheaper; and so it will be of many other farm products, when these markets are once established.

We have dwelt thus at length on the general advantages of regular fairs or market days, if established throughout the State; let us now consider some of the particular benefits to be derived from them. Every farmer wishes, more or less times in the year, to purchase livestock, either young animals to keep over winter, stores to fat, milch cows to recruit his dairy, or working oxen, or a bull, or a horse, or swine, sheep or poultry. Some of these are sure to be needed by him, and he must either ride round among the surrounding farmers, or he must go to Brighton or Cambridge, to make his purchases. The former course is attended with much loss of time and vast uncertainty of finding the precise animals wanted. The latter involves much expense, and the inconvenience of making the desired purchase at a distance from home, which distance must be travelled by the animals as well as himself, to reach home.

Now, if there were a cattle fair held monthly or quarter-yearly in his neighborhood, he might at a trifling expense resort to it with the certainty or bigh probability of making his purchasés, and he can return with them the same day to his farm. Or suppose that he has an ox which he wishes to mate, he can drive him to the fair and he may there meet with another farmer similarly situated, and thus the two are brought into a position to make some sort of a trade, which may be mutually advantageous. Now these men might have ridden about a week or more exploring barnyards and fields for an odd oxand what farmer's experience does not illustrate the supposed case? - and perhaps be unsuccessful at last.

Again, many farmer's wish to purchase in the fall young stock to keep over winter, generally heifers expected to calve in the spring. Heretofore, when cattle travelled on foot in droves to the Brighton market, they came so near their doors as to present a good opportunity for such farmers to make their purchases. But now live-stock is mostly transported to the large markets by the rail cars, and there is hardly any alternative for the farmer to make his purchases, but at these distant markets. Were local fairs or market-days established, then there would doubtless be droves of cattle purchased at the large markets at Cambridge and Brighton, and driven down to such fairs to supply the demand there. The farmer could then have his choice of such stock and at a price that while it would leave a fair profit to the drovers, would be less than he could afiord to pay at a distant market. This would occur only in districts where there were not young animals enough raised, to supply the local demand.

It may be, too, that among the benefits to be derived from establishing regular fairs throughout the State, would be the encouragement they would thus indirectly give to stock husbandry, a branch of husbandry of late sadly neglected by us. The farmer is now tempted by the ligh prices offered, to sell his best calves at an early age to the butcher. And in fact their slaughtered carcases are brought by the ears and by steamboats from New Hampshire, Vermont and Maine, to supply the Boston market. Tlus the number of neat animals 
raised to maturity, has not kept up with the wants of the community, and as a consequence the price of beef animals, milch cows and working cattle, has experiencerl a most unprecedented increase. If the farmer could find purchasers for two-yearoold leifers and steers, as readily as for ealves and at corresponding prices, what should hinder lis making the attemplt to rear them? It will be sabl perlaps that he has not the fodker to keep them over winter in any numbers, without encroaching on the feed of his other stock. Now here is just where he should rouse himself to more enterprise to meet this want, especially by the cultivation of root crops. It is remarkable what immense burdens of carrots, ruta-bagas, mangel wurzels and sugar beets, can be raised on small plots of well-manured land, and with no more skill and labor than are required in the cultivation of a corn erop. The turnip-culture is often said to be the foundation of modern British husbandry. Why? Because it enables the firmers of Great Britain to rase and keep a much larger number of animalsboth neat stock and sheep-than they would otherwise possibly be enabled to do, and by this means to increase the manure heaps by which to augment the capacity of the soil for future crops. We have talked a great dial about the benefits of the root culture-it forms one of the standing topics of cattle show addresses-but it has made but slow progress among us. If we would once set about it in good earuest and begin to rear young stock, we should know by actual experience the inestimable value of roots for winter feeding, and should help introduce into more general practice their culture. And the prospect of a home demand for young stock-such as would spring up from the establishing of market-days - would certainly tend to this desired result.

Again, there is a growing demand and at high prices, for good milch cows, especially for those giving rich milk, well adapted for the table and for butter. Let a regular market-day be established in their neighborhood, and an additional inducement would be offered to farmers to raise their most promising lieifer calves, by the certainty of finding purchasers of their cows, just as soon as they were ready for sale ; and the competition of a full attendance of purchasers would most likely create brisker sales and higher prices than would otherwise be had for them. The great question which is the best breed of cows for dairy purposes - if indeed there be one-would after a time be in a fair way to be settled. If the Jersey or the Ayrshire breed be the best adapted to our pastures and our climate, and the most to be depended upon for the dairy, it would assuredly be found out; for at a Fair where dealers and farmer's thus meet together, they would compare their experiences and make up a judgment accordingly. Or if a new breed of milch cows-pure natives perchance-should he originated among us, that should meet all our requirements, that would then be the one to receive the most attention to propagate it in its purity. Why? Because quick sales, large prices and a certain market at our very doors, would operate as a stimulus to such stock raising, and it would be seen that it would pay, when we returned from the market with the proceeds. 
So too we should raise our pigs, instead of being dependent, as for years we have been, on New York and Ohio for our supply, notwithstanding the disease which lias proved of late so fatal to those brought from these States. 'The loss from this source to the farmers and drovers of Massachusetts has been immense. Can any one say, in view of such a loss, that its recurrence should not be guarded against by increasing the number of breeding sows, and making a home market for their litters by the establishing of regular markets for their sale? They can readily be taken to market in wagons fitted for the purpose, or they could be driven in droves, if grown to be shoats, and the supply, it is safe to predict, would not for a long time, if ever, exceed the demand. And here too, as in the case with milch cows, there would be greater inducements, by the establishing of such markets, to bestow more attention to breeding than has as yet been practiced among us.

Let us come now to farm products other than live stock,-how would they be affected by the establishing of these fairs? Some products, such as hay for example, would hardly be offered for sale, unless it should be pressed in bundles so as to be made arailable for transportation. Wherever grains were grown in any considerable quantities, they would rarely fail of finding purchasers at these fairs, for it is well known that the supply of these have not for a long time been at all adequate to the wants of the State. And it is equally well known that the Indian corn and the rye raised in New England, is far superior in quality to that imported from the Middle and Southern States-for domestic consumption, indeed, no one having tasted of the former would use the latter, unless from sheer necessity. Butter, cheese and eggs, articles that are now frequently sold at the door to travelling agents, or at country stores, and without any competition to enlance their price, would be brought to these fairs in sufficient quantities to attract purchasers for the larger markets, and sales would be made at their full value and for ready cash payment.

In regard to apples, large quantities of which are some years raised in the State, the advantage of regular market days or fairs for their sale, would be very great. As they are a bulky article, their transportation to market is no trifling affair. Six or eight barrels are usually taken at a load in a one-horse wagon, requiring on an average thirty trips to sell a crop of two hundred barrels, besides the time consumed in finding purchasers. Now if the farmer were sure that on a particular day in the fall, dealers would attend the fair in his neighborhood, and make large purchases of this fruit for shipping or for re-sale at the larger markets, he could take with him samples of his different varieties, and thus dispose of his entire crop, to be delivered at the cars or in the city, as might be agreed upon. By this comparatively small outlay of time and money, his net profit would be vastly greater than it now is. In the same manner, onions and other vegetable crops might be disposed of with advantage, both to the seller and the buyer.

And here we are reminded of an incidental advantage to be derived from these fairs, and one by no means to be overlooked in forming a 
correct estimate of them. Some crops, such as the apple, for example, are extremely variable, being one year abundant in some parts and scarce in others; and another year, vice versa. Some crops tou, such as the onion, are raised in large quantities, in some sections of the State, and not at all in other sections. Now an abundant supply of any commodity gluts the market, and often reduces prices to a ruinous extent. Hence, where there is an excess of these crops beyond the demand for home consumption, it could readily be disposed of to purchasers from a distance, who would be drawn to the local fairs by the knowledge of this very contingency.

Besides the opportunity thus afforded for traffic at these fairs, they would be attended with peculiar convenience to the farmer in hiring laborers. He is now put to great trouble and uncertainty in obtaining such as are needed-doubtless owing in part to the fact that native labor has been of late largely superseded by foreign. But even this labor cannot always be commanded at the time it is most wanted by him. He cannot spend much time in the busy season in riding round for work-people, and unless they happen to offer themselves at his door, he must suffer for want of them. Now at the opening of the spring work, at haying and at harvesting, if the farmer could be sure of meeting at the fair in his neighborhood, a large number of men in want of work, of whom he conld take his pick, it would assuredly be no small convenience both to himself and to the persons hired. From this arrangement, a scale of prices, which would be highly desirable, would soon be fixed for the different kinds of laborers, and as a consequence there would be more uniformity of wages paid by our farmers. And if it were deemed expedient, a registry might be opened for the names of the persons thus seeking employment, and of the place where they last worked.

But it would be difficult to specify in detail, all the benefits, which might be expected to be derived from establishing regular fairs or market-days throughout the State. We have endeavored to enumerate but a few of them-sufficient, lowever, to give some definite, and it is to be hoped, favorable views in regard to them. Doubtless here, as in other new enterprises, many of the advantages would far exceed the most sanguine expectations, whilst others would in time spring up that were entirely unlooked for. Take for illustration, our railroads-many of us can remember with what distrust they were regarded by a large part of the community, when they were first proposed for consideration. The stage-coach companies thought that they should be ruined-and the farmers reasoned very naturally that the general introduction of the iron horse, as a means of transportation, would diminish if not destroy the demand for hay and other provender. But how has it turned out? The starge companies hare becone the proprietors of the omnibuses running from the various stopping-places of the rail ear's. And for the use of those omnibuses, and for drays, coaches and private vehicles, and more recently for horse railroads, the number of horses in the State, and their price too, has probably doubled or trebled since the first rail was laid here, and the consumption of hay and oats has increased in a corresponding 
ratio. Other interesting particulars will 1 eadily suggest themselves, illustrative of the incidental benefits of railroads, equally unforeseen by their projectors and the community at large.

Let us now consider some of the objections that would be likely to be urged against the establishing of these fairs. It may be said perhaps that they propose too great an innoration on the present modes of disposing of agricultural products, to meet with much faror from the farming community. We all know with what reluctance farmers quit long established habits and practices, and how slow they are to make any change in them. Nor can it be denied that a most radical change is here proposed to them, and one which needs to have a fair start given to it, in order to overcome the standing objections to every new enterprise. To take again for illustration the case of railroads, when they were first talked of, the conservative men on all sides cried out agatinst this change from the long tried and well approved modes of travel on the public highway. 'Those in any way interested in keeping things as they were, joined in the cry of "let well enough alone."

"But," says J. R. Williams, in an address before the Michigan State Agricultural Society, in 1sวّ", when speaking of the old maxim that it is best to "let well enough alone," "it depends upon what "well enough' means. As a maxim for a farmer it is pernicious. I hold in my hand two peaches. They grew upon trees which sprung from different pits of the same original tree. 'This large, blushing, richlytinted, melting, thin-skinned and small-stoned peach, is cultivated fruit. The small, woolly, tough-skinned and large-stoned peach, is the natural firuit, the 'let well enough alone' kind. I hold in my hand two apples, plucked from the same tree, one firom a grafted, and one from a natural branch. One is the cultivated firuit, the other is the 'let well enough alone' kind. You perceive the distinction is as marked in the apple as in the peach. 'These are a type and fit illustration of progress and perfection in every branch of agriculture."

Notwithstanding the doubts of some, and the gloomy forebodings of others, the railroads were started and they who at first were most opposed to them, have been as ready as any to avail themselves of their benefits. So it would most probably be with these fairs-once started under favorable circumstances, they would give the best proof, by actual experiment, of their superiority over the present modes of selling and buying agricultural products. It would doubtless take time to turn the current of trade into the new channels-but it would come-and the wonder would then be that the work had not been undertaken long ago.

It may be objecterl to these fairs, too, that they are not adapted to the habits of onr people-that they partake too much of the character of holidays to be favorably received by them. But, it may be asked, how can this be determined without making the trial? In fact, it is in our power to give to them just such a character as we please. And should they become the means of inducing our farmers to spend a few hours occasionally in innocent and rational recreation, it may well be questioned whether the effect on their minds or morals would be at 
all injurious. It is the bow that is always bent that loses its elasticity, so the mind that is constantly intent on business and is never unstrung in social intercourse, loses its quickness of perception and its keenness of judgment; the heart that is never warmed into a genial glow of cheerfulness and pleasure, becomes cold and torpid. We should not be sorry to see as an effect of these fairs, more of the "good humor and all social affections and generous sentiments among the people," which the Constitution specially enjoins upon legislators and magistrates in all future periods of this Commonwealth to countenance and inculcate.

Other objections might be raised to an enterprise so novel and untried as this would be among us. It is not necessary, however, to go into the further consideration of them for the reason that we cannot conceive of any sufficiently serious to require it. It should be borne in mind that the practical question is, not whether there are any evils to which these fairs might be liable, but whether they would be overbalanced by the positive benefits resulting from them. And this question could best-and perhaps only, be settled by an actual experiment of establishing them. And this brings us to the consideration of the best practical method of commencing and continuing these fair's throughout the State, so as to create new markets for the farmer.

And first it would be highly desirable, if not essential, that the farmers of the Commonwealth should be more fully informed as to the working of these fairs and the advantages to be expected from them, in order to their co-operating with earnestness and energy in their establishment. If it be true-and of this it is too late to doubtthat "where there is a will there is a way," the first great object in starting this enterprise is to secure the hearty good-will-the intelligent and the united will of the farming community in its favor. This, we are persuaded, is vital to its success. With this riew, meetings might be held in the winter months in the different counties, the question fully discussed and a vote taken upon it. A series of such meetings might be held in different parts of the same county, until the subject was brought before its whole agricultural population and their minds were known, with some degree of certainty, upon it. And in addition to this, circulars might be issued by the State Society, to be distributed through the County Societies, setting forth the advantages of these fairs, and requesting the opinions of those to whom they were addressed, as to the practicability of establishing such fairs in their several neighborhoods, and the times and places at which they could best be held, also desiring each person to say what part, if any, he would take in giving them his support by his attendance and otherwise. When all this had been done, we should be in a position to judge wliether it were advisable to proceed in establishing the fairs, or not. If the whole popular current was decidedly against it, or such a degree of apathy and indifference was manifested in respect to it as to make its success highly doubtful, then we should say that it was best to wait for "the good time coming," rather than to attempt to force its advent. But if the public sentiment, as thus 
ascertained, were favorable to the undertaking, especially if a certain enthusiasm were excited in the subject, start it then, by all means, and the sooner the better. There need be but little formality about it. Let individuals in the several neighborhoods near the fair, associate themselves together by agreeing to attend, either to buy or sell, one taking this and another that article, and all determining to lend his aid and encouragement to it. One enthusiastic person in a neighborhood-an energetic, persistent man, not easily deterred by trifles, one that sees few or no obstacles in the, way when a good enterprise is started; or, seeing them, summons fresh pluck to surmount them, will certainly succeed in enlisting the hearty good-will and cooperation of nearly all with whom he comes in contact. With book and pencil in liand let him call on his neighbors and talk over the matter freely with them, and then note down what this one and that will do to help on the fair,-specifying the articles they would severally agree to carry to it. The power of associated action and the force of example, would in this way operate quietly but effectually. A few such men-young men, if they can be enlisted-will act like leaven to leaven the whole mass.

There need be no regulations made and published as to the buying and selling, not even that the sales sliall be for cash payments, which would certainly be the most desirable mode of trade. The fair would be the farmers' exchange-just as the merchants have their excliange in the city-where they meet to transact business, and self-interest and mutual convenience make the bargains. Neither are there needed any public yards or buildings for the display of animals or other products of the farm; but they would be offered for sale at particular points, which would soon become well known to the public. On the $23 d$ of June last, Sanford Howard, of the Boston Cultivator, attended a cattle fair at Kilmaurs, in Scotland. In a letter published just afterwards in that paper, he says, "there were there about four hundred head of cattle, mostly Ayrshire cows and heifers, the greater part of which changed hands, although the market was dull. They were collected in the principal street of the village, the lots of the different owners being kept separated by men and dogs. The purchasers looked over the animals, and having decided on the ones they wanted, and asked the price, made offers, at the same time extending their hands. If the offers were accepted, the parties shook hands and that consummated the transaction." The whole is a very simple affairas simple as Columbus making the egg stand on its end-if we would but take hold in earnest and determine to have it succeed. Only make a beginning by collecting together on a fixed day and at a fixed place, agricultural products and men in sufficient numbers, and the market is established. The success of one such day would be almost sure to command success on the next, and after a few such days the market-day would become a permanent and popular institution, and would be noted in the almanac, as the different terms of the Courts are noted.

Another important question, and one requiring much care and deliberation in deciding it, is, how often and where shall these fairs be 
held? It is clear that this must be left with some body of men, in whom the public have confidence. The different Agricultural Societies that receive the bounty of the Commonwealth, and are required to make an annual return to it of their transactions, might be requested to take upon themselves this duty. Composed as these societies very generally are of farmers, they have the confidence of the farmers, and they can best fix the times and places of the fairs, with the proper discretion. By their trustees, or by committees cliosen for the jurpose, they might exercise the necessary power with regard to the whole matter, with but little danger of its being abused. They should, in the first place, map out the county, and then select such points as would best accommodate the population, having reference to railroad and other facilities. The railroad companies could well afford to encourage the fairs, by charging but half-price to those who pass over their roads to the market. To make this matter more specific, let us take for example the County of Essex-that being the county with which the writer is most familiar-and let four towns be fixed upon as near as may be to its four corners, as the places where monthly fairs or market-days shall be held throughout the year. Such four places might be Danvers, (at the Plains,) Ipswich, Newburyport, and North Andover, (at Sutton's Mills.) Three of these towns have at least two railroads running directly to or through them; and one, Ipswich, has the Eastern Railroad passing through its center. Having settled upon these towns and the points in them, at which the market could best be held, on the first Wednesday in January let a market be held at Danvers, due notice having been given to that effect. On the seeond Wednesday in Jannary let a market come off at Ipswich; the third Wednesday at Newburyport, and the fourth Wednesday at North Andover, and so go through each month in the year, observing the same order as to the days. In this way, it would soon be known that the first Wednesday of every month was marketday at Danvers, and so of the other towns, they would always have the same Wednesday in the month for their market-day. At first these markets might not be so fully attended, but still they should be observed, rain or shine, brisk times or dull. As the fairs are started, in respect of place and day, so they should be continued, for the reason that a change would be difficult; but more especially that the habit of attending a particular market at a regularly recurring time, would thus become fixed in the life of the farmer. And in order to accommodate the whole county by a larger display of stock, let some central town, such as Topsfield or Georgetown, having good railroad facilities-be the place for holding a market day for neat stock and horses in the spring and fall, the first Friday in May and October being suitable days for that purpose, and not interfering with the other markets.

And in order to encourage this whole enterprise in its infancy, it might be advisable for the Agricultural Societies or public spirited individuals to offer premiums for certain farm produets, that eannot so well be presented at the regular cattle shows, and do not receive any encouragement from them. For example, the best poultry in all 
its varieties, dressed for the market, mutton, pork, veal and other meats, might thus be noticed. The best lot of honey and eggs, of butter and cheese, of cranberries, quinces and apples, and of fruits and vegetables generally, might also receive the fostering aid of the societies. The advantage of this mode of bestowing premiums is, that it would be the best lot of a given product, as prepared for market and exposed to sale, that would receive them, and not the best specimens, culled and fitted for parade, as is too often the case at our fairs. 


$$
\text { [NEW SE. } 4 .
$$

$\boldsymbol{A}$

\section{PRIZE ESSAY}

ON THE

\section{PREPARATION AND APPLICATION \\ or}

\section{A N URES.}

BY

JOSEPH REYNOLDS, M.D.,

oF CONCORD, MASS.

B O T T N :

1858 .

J. H. EASTBURN'S PRESS. 



\section{E S S A Y.}

Is treating of the preparation and application of Manures, several other points naturally, and almost necessarily suggest themselves. In discussing their preparation, one can hardly avoid inquiring into their composition, and the sources from which their component elements are derived, and before one is prepared to apply them, he must ascertain the effects which they produce, for it is by a careful observation of these effects, that he is to be guided, rather than by rules derived from theory.

\section{The Preparation of Manures.}

In considering the best mode of preparing any substance, we must obviously ascertain, at the outset, of what it consists. Our first inquiry then must bé, what elements are essential to constitute any substance a manure.

To this inquiry I reply,

\section{1st. Mantres}

consist of carbonaceous matter already combined with oxygen, or in a condition to be combined with it, thus forming carbonic acid. Carbonaceous matter is formed by the decay or decomposition of the woody fibre of vegetables, of starch, gum, sugar, and oils, into the composition of all which, carbon largely enters. Carbon constitutes the firamework, or chief bulk of all vegetables, and is left, more or less free from all other elements, in decayed regetable substances. It constitutes the bulk of all the solid exerementitious matter, which passes through animals. Hence all ordinary manures, whether consisting of animal excrement, or of vegetable matter, in the form of muck, decayed grasses, straw, leaves, fruit, wood or other vegetable growths, are composed very largely of carbon.

\section{2d. Salts.}

Manures contain the salts of lime, potash, soda, magnesia, silex, ammonia, sulphur and iron, all of which, except ammonia, are found in vegetables, and are derived from the soil. 'They are all found, also, in the secretions of animals, especially in their liquid secretions, being derived by them chiefly from the vegetables on which they feed. Ammonia is abundant in animal secretions, being formed in them by the chemical union of nitrogen and hydrogen. This is an important element in many manures, as it furnishes for the use of plants, nitrogen and hydrogen, and also operates as a stimulant to their secreting and assimilating vessels.

What are called animal manures, which consist of decaying animal substances, as flesh, hair, feathers, skins, \&c., yield a large quantity 
of ammonia, it being formed in the process of putrefaction, by the chemical union of their nitrogen with the hydrogen of water.

\section{3d. Gases.}

Manures contain elements in the form of gases, as oxygen, hydrogen, nitrogen and their various compounds with other substances, as sulphuretted hydrogen, consisting of sulphur and hydrogen; phosphuretted hydrogen, composed of phosphorus and hydrogen; and carbonic acid, compounded of carbon and oxygen. Ammonia usually exists in manures in a gaseous form, except when combined with sulphuric or other acids.

\section{4th. Acids.}

Acids, either in a free state or combined with alkaline bases and metals, are also found in manures; as sulphuric, muriatic, nitric, phosphoric, carbonic acid, \&c. These acids, with the exception of the carbonic, are seldom found in a free state, but generally in a state of combination; as sulphate of lime, nitrate of potash, phosphate of ammonia, \&c.

\section{5th. WATER.}

The fifth important element contained in manures, is water. This contains in solution, the earths, acids and gases. It is the universal solvent employed by nature, and is always present, when vegetable or animal growth is going on, furnishing to the vessels of the different organs, in that state of minute division, which can be obtained only by solution, the elements which they require to construct their rarious tissues, and not only so, but freely yielding up the oxygen and hydrogen of which itself consists, when one or both are required. These elements, viz. : carbon, alkaline salts, silex, sulphur, iron, gases, acids and water, are the elements usually found in manures. They are rarely all found in any one manure, and are found in different proportions in different manures. Hence thedifferent effects of different manures. Manure consisting chiefly of carbonaceous matters, when applied to soils containing a large percentage of humus or carbon, will produce but little effect upon the growing crop. Such a soil requires manures containing a large quantity of alkalies or nitrogenous matter. A manure consisting largely of carbon, is specially adapted to sandy loams, from which the carbon has been exhausted.

\section{How many of the elements above named are necessary to constitute a manure?}

In order to answer this question understandingly, it is necessary first to determine the condition of the soil to which it is to be applied, for that may be considered a manure, which supplies any want of the soil; and secondly, the elements specially wanted by the crop to be cultivated upon it. All the constituents above named are necessary to furnish a perfect manure; that is, a manure that shall be suited to all kinds of crops, in all kinds of soils. But were all manures so constituted, it is probable that a portion of the elements would be wasted in all eases; or, in other words, that they would not 
all be wanted, in any one case. Several of these elements are volatile in their character, and of course, will not remain permanently in the soil. If they are not wanted for the immediate crop, there will be a waste of material. Could we determine, in all eases, the wants of the soil, and the wants of the crop, and then apply only those elements of manure that will meet these wants, it is obvious that a great amount of material would be saved. But the difficulties in the way of determining these wants, and of so combining and adapting the needed manurial elements, are so great, that they can never be wholly overcome, and we must be content to submit to the loss resulting from our ignorance and inability. But science and observation maty do something towards meeting these difficulties. Here is a fine opportunity for the exercise of the discrimination and judgment of the cultivator.

Having now spoken of the elements contained in manures, we are prepared to speak of the sources from which they are derived, and of their preparation. Carbonaceous matter, as we have seen, results from the natural decay or chemical decomposition of vegetables. Accumulated masses of regetables, as leares, wood, grasses, straw, the stalks and stems of all plants, fruits, roots, grains, \&c., under favorable conditions, rapidly undergo, first, the fermentative, and secondly the putrefactive process. By favorable conditions, is meant the proper degree of temperature, and the proper amount of moisture. When there is too much or too little heat, or too much or too little moisture, the process of fermentation will not go on.

When masses of regetable matter are collected under favorable circumstances, their fibres soften and swell, and become permeable to air and water. Their salts, starch, sugar and gluten and extractive matter are dissolved; their carbon combines with oxygen, and carbonic acid is rapidly formed, and permeates the whole mass. This acid combines with the alkalies that may be present, and thus carbonates of lime, potash, socka and ammonia are formed. After a time, certain elements in the mass take on the putrefactive process. This process is due chiefly to the presence of gluten and nitrogenous elements, sucl as those derived from animal sources. Animal substances rapidly pass into the putrefactive process, and the larger the proportion of such substances combined with the regetable masses, the more rapidly putrefaction oceurs.

Hence the addition of a portion of animal manures to vegetable matter, greatly facilitates putrefaction and decomposition. By this process, nitrogen is set at liberty, and combines with the hydrogen of the water, or with that which it finds in a solid form in the vegetable substance, and forms ammonia, which, combining with the carbonic acid which is being rapidly evolved at the same time, forms carbonate of ammonia, the form in which ammonia is usually presented to us. Hydrogen is also rapidly developed by the putrefactive process, and combines with sulphur and phosphorus when present, forming sulphuretted and phosphuretted hydrogen, the gases which so offend our sense of smell in manures. These gases are highly rolatile, and when the surfaces of the putrefying mass are freely exposed to the atmosphere, are rapicily dissipated. Some substances have the power 
of absorbing a large amount of these gases, and of retaining them with considerable tenacity. Carbon itself, when nearly pure and dry, has a strong affinity for them. Hence the addition of dry pulverized charcoal or of peat, will absorb them in large quantities. From this property is derived the power of these substances, as deodorizers. The sulphates of lime, iron and zinc have a similar power. 'These sulphates have also the power of decomposing carbonate of ammonia, displacing the carbonic acid, and forming sulphate of ammonia, which is not volatile. Sulphuric acid, nitric acid, and chloric acid will decompose carbonate of ammonia, forming sulphate, nitrate, or chloricle of aminonia, which salts are not volatile. Hence the value of these acids to combine with alkalies, and especially with ammonia, forming with them soluble salts.

The result, then, of decomposition as we nsually find it, in the form of regetable compost, is carbonaceous matter, combined with certain salts.

Vegetable substances are also decomposed in the digestive organs of animals, by a process, in many respects, similar to that which we have already described. The vegetable fible is comminuted by the teeth, and softened and permeated by the fluids contained in the organs of the animal. A large portion of the starch, gum, sugar, gluten and salts, are dissolved out, and taken up by the lacteal vessels of the animal, to serve the purposes of nutrition. The remainder, mixed as we have said, with the juices of the animal, containing in solution various substances, is ejected. This process is accomplished much more rapidly than the ordinary process of regetable decay, and the substance resulting is mixed with a large amount of animal matter, which fits it for rapid putrefaction. 'The animal matter acts the part of a learen, which sets up the putrefactive process, whenever the necessary conditions are present. There is this difference between the reduction of regetables by the ordinary process of composting, and by the process of animal digestion, viz.: that in the latter process, vegetables are made to afford nutriment to animals, while undergoing reduction, and yet in consequence of the condition to which they are bronght, and of the additions which they receive, they are more valuable as manures, than when, withont serving the purposes of nutrition, they are reduced by the former process. These two processes, vegetable composting, and the feeding of animals with vegetables, are the sources from which carbonaceous manures are chiefly obtained. But the slow decomposition of regetables is always going on in nature, and thus one generation of plants is made to afford nutriment to those that come after it. The carbonaceous matter resulting from the decay of regetables, is not all taken up, as it is formed. Immense masses of it have accumulated in meadows, swamps and basins, by the action of obvious causes.

These accumulations of vegetable debris, mingled with more or less of insoluble earths, constitute muck or peat, and are capable of furnishing an almost unlimited amount of carbonaceous matter, in a condition to be made rapilly subservient to the purposes of cultivation.

'This material differs considerably in condition, and in composition. In some deposits, it is much more purely carbonaceous matter, than 
in others. In some, the decomposition is more complete than in others. But the most important difference in diflerent parcels of muck is, that one contains acids, or minerals combined witl acids, in very sensible proportions, while another is nearly or quite free from such compounds. When acids abound in muck, it is unfit to be used in a simple state, but needs to be corrected by alkalies; and of these, lime seems to be the best adapted to remedy the evil. Quicklime mixed with peat, has the effect of rapidly rendering it pulverulent and light. Its influence seems to be extended through the whole mass, like that of yeast through the whole mass of dongh, while at the same time, it neutralizes the acids, and decornposes the salts of iron or other minerals, forming salts of lime, which themselves are essential to the growth of many crops.

When muck is free, or nearly free from acids, it may be used by itself, with great profit, on light sandy soils, or on any soils, in which the humus is exhausted, or it may be composted with stable manure, ashes, guino, or animal matters, with peculiar advantage, since it has, as we have already observed, the power of absorbing and condensing the gases arising from the putrefaction of these substances, and thus will be formed a manure adapted to nearly all the uses of the garden and the field. No other substance seems so well adapted to composting with night-soil or urine as muck, since it deodorizes these substances, and retains all their valuable elements, and renders them at once manageable, and easy of application, and affords the dilution which concentrated manures require for their safe application. Composted with putrefying fish, it forms an exceedingly valuable manure. The best mode of preparing muck for use, is to throw it from its bed in the autumn, and let it be exposed to the action of the frosts of the succeeding winter. If it is designed to be composted with lime or ashes, it may be used the following season. But if it is to be composted with stable manure, night-soil, or animal matters, it is better to let it remain until the following autumn, when it should be deposited in the barn-yard or cellar, and be mixed with the droppings of the animals, from time to time. It should be provided in sufficient quantity to be used freely as a deodorizer about the premises, whenever or wherever it may be wanterl. It will thus become charged with gases and salts, and be converted into a highly valuable manure, especially serviceable in garden culture.

'The chief sources of carbonaceous matter are then found in vegetable composts, animal excrements, and muck, and combined with them, as we have seen, are various salts and gases. But these elements, which are equally essential to vegetable growth, either as component elements, or as stimulants, may be found in more concentrated forms, in much smaller bulk, and capable of more easy and direct application to plants. These fertilizing elements, variously combined and condensed into a small bulk, constitute what are called art'ficial manures. All plants take from the soil more or less inineral matters. Some require them in large quantities. Such plants are said to be exhausting to the soil on which they grow. The small grains, which appropriate in their culms and seeds, a large amount of silex, lime and potash, are instances of this class. Other plants take less from 
the soil, and feed copiously upon the elements found in the atmosphere. The turnip and cabbage, which are furnished with a large array of leaves for this purpose, are an instance of the latter. The elements to which we now refer, are all soluble, and are dissolved and washed out of the soil by the rain, and from land that is well worked and in fine tilth they are rapidly washed out, and, unless they are supplied by artificial means, the cultivated soil becomes rapidly deprived of them. 'These elements may be directly and easily supplied to the soil. The nitrogenous manures, as guano, night-soil, poudrette, urine, hair, fish manure, and animal substances generally, contain in solution, or in combination with acids, a large quantity of mineral matter, chiefly lime, potash, and ammonia, and it is to these that they owe whatever permanent value they possess, their other elements being so soluble and volatile, that the effects of this class of manures are immediate and temporary.

Another kind of nitrogenous manures to which but little attention has been paid in this comntry, may be found worthy of attention. I refer to nitre beds, which are formed of soil mixed with potash, lime and soda, and are protected from the rain by roofs open on all sides, to expose them to the free circulation of the air. The mixture is frequently stirred to expose new surfaces to the air. The alkaline substances thus treated, combine with the nitrogen of the air, and thus in time, nitrates of lime, potash and soda, are formed, and the whole mass becomes strongly impregnated with them. The principal use that has been hitherto made of the substances thus treated, has been to leach tliem, by which the nitrates of potash and soda are dissolved out, and reduced to a solid state, by evaporation, for the manufacture of gunpowder, and other purposes in the arts. There can be no doubt, that large quantities of manure might be thus prepared, which would be highly valuable. Experience only can determine whether it can be done economically. But the principal means by which mineral matters are restored to the soil, is the direct application of lime, gypsum, bones, ashes, salt, sea-weed, and nitrates of lime and soda, and muriates of lime, soda and ammonia. The effects of such substances upon many soils are very apparent, especially when their application is followed by crops, into whose composition such substances largely enter, as wheat, oats, potatoes, \&c.

Having spoken somewhat at length of the composition of most of the substances in common use as manures, I will speak briefly of their preparation. It has already been seen, that most of the natural manures contain elements that are soluble and volatile. It follows, of course, that when such substances are exposed to the rain and snow, the soluble elements will be dissolved and washed out, and that, if they are exposed to the free action of the atmosphere, their volatile elements will be dissipated, as fast as they are developed, and this will be, at least with respect to several of them, nearly in proportion to the elevation of the temperature. The free action of the air will not only dissipate their gases, but will carry off the moisture which is necessary to support chemical action. Hence it follows that in collecting and preparing manures for the soil, whether they consist of unmixed stable manures, or these composted with soil, muck or other 
vegetable or animal substances, they should be protected from the action of the weather. 'There are few who ean afford to submit to the loss to which they wonld otherwise be exposed. 'The harn cellar is perhaps the most eonrenient amangement for the protection of manures, and this is coming rapidly into use throughont this State. 'The cellar should be easy of access,-should be male with a bottom impervions to water, protected firm currents of air, and if possible secured from fiost, so that the fermentative and putrefactive processes may he going on through the winter. Material should be provided and placed in or near the cellar, and be spread frequently over the fresh droppings of the animals, that it may absorb the liquid portions, and absorld the gases as fast as they are formed. 'The materials provided should be as dry as possible, that they may retain the liquid excrement, and besides, in a dry state loam and mock are more easily pulverized, and mix more thoroughly with the droppings. If the inass, thus gradually formed in the cellar, is suffered to fireeze, very little decomposition or chemical action take place during the winter. But if the firost is kept out, the laboratory will be at work more or less actively, through the entire winter, and the manure will be fit to be used in the early spring. It will become softened and rendered fine, by its own internal action, and will not require to be overhauled, for the sake of breaking and pulverizing it. Whereas, if it is kept frozen, or near the fieezing point, the animal excrement will be in the condition of green manure, and will not so readily combine with the soil, or act so immediately upon the growing crops.

'The farmer who has no cellar, should cover his manure with a roof, at least, to protect it fiom the rain and sun. It would be well for the furmer who does not cover his manure, to remore it during the winter, into his field, and deposit it in as large masses as possible, that it may present the smallest surfice to the weather, and corer it neatly with soil, that may protect it from the rain, and absorb the gases as fist as they are formed, which will be very slowly during the cold weatler. A quantity of dried muck may be provided in the autumn, near where it is intended to deposit the manne from the barn, and be mixed with it as it is deposited, and used to cover the heap. Heaps of compost this preprared, require to be oreshanled in the early spring, and the ingredients to be well mixed. It is an excellent practice to mix with them, as they are being orerhauled, gypsum, or a solution of sulphate of iron, or diluted sulphurie acid, as these will combine with, and retain the ammonia, as it is formed in the fermenting mass. Ashes or quicklime should never be directly combined with green mature, or urine, or any substance, as guano, for example, which continins a large amount of carbonate ef ammonia, as they will combine with the carbonic acid, and set free the ammonia in a gaseous form, which, unless some other substance having a strong atlinity for it, is present, to combine with it, will of course be lost. When it is desilable to apply line or ashes to the same suil with stable manure, or compost eunsisting partly of stable manure, the best method probably is, to plough in the manure, and spreat the lime or ashes broadcast orer the surface, or apply it in the hill with the seed, when hoed crops are to be cultivated. 'The principle, which should 
ever be kept in view, in the preparation and application of manures, is, that they should be applied to the soil in their integrity, that is, containing all the elements belonging to their constitution. If a portion of these elements are diffused into the atmosphere instead of the soil, it is obvious that a portion has been lost, and that portion is usually the most active and the most stimulating. Some persons prefer to introduce stable manures into the soil, in a crude or green state. In this condition it is in a state of integrity, and all its elements, as they are developed, are absorbed by the soil, and we are not surprised that those who have never experienced the advantages of composting in a cellar, should prefer this mode of application.

We have already referred to the combination of muck with nightsoil. Probably there is no better mode of preparing this highly valuable substance for common use, as a manure, than by mixing it with a sufficient quantity of muck in a dry state, to absorb its moisture, and destroy its odor. If a quantity of plaster, or a little diluted sulphuric acid be added to this composition, we shall have one of the best manures that ean be composed, for most crops, and especially for garden and fruit crops.

\section{Liquid Mavures.}

The saving and use of liquid manures is deserving of more attention than it has yet received in this country. It is easy so to arrange the stalls of cattle, as to receive their urine into troughs under the floor, and to convey it into a cistern in the cellar, or outside of the barn. This may be pumped into a water-eart, to which a sprinkler is attached, similar to those used in watering the strects. If it is pumped in through a strainer, the sprinkler does not become clogged, and it may be rapidly conveyed to the field, and distributed as a topdressing, upon grass or grain, with immediate effect. When the soil is not deficient in carbonaceous elements, there can probably be no better top-dressing applied. It is not as permanent in its effeets as the solid excrement, but more immediate, and it may be applied twice a year upon grass, with less expense of labor than one dressing of solid manure. The cost of the neeessary apparatus for saving and distributing it, is small. As a top-dressing for a field where turnips are to be grown, it is very excellent. As a top-dressing in the spring, or during the summer, for pasture lands, it is perhaps superior to any dressing that ean be applied. If the undiluted urine is thought too strong, it may be easily diluted in the field, if water is at hand. A gentleman of my acquaintance, who has been using it as a top-dressing for grass, during the three years past, considers it fully equal in value to the solid excrement of the same animals, and he states that one man can dress as much land in this way, in one day, as two men ean, with solid manure, in two days, without taking into account the expense and labor of collecting and mixing the material of which compost is made. If this statement be correct, it must be more economical than any compost, as a dressing. When applied to land in which humus is deficient, it will not probably be found to meet all the wants of the erops. Its effects will be much like those of guano, on similar soils. It remains to be determined by experience whether 
it is of equal ralue with superphosphate of lime, ashes, plaster, guano, or other concentrated manures, as a top-dressing. These may all be applied with equal facility, and with even less labor, and some of them, as ashes and lime, are more permanent in their effects. In applying liquid manure as a top-dressing, the labor of one man and horse will top-dress an acre in a day, within a quarter of a mile of the barn. This would be worth not far from three dollars. Will that value of any other dressing add as much to the amount of the grass or grain crop as will the dressing in question? This must be determined by experiment. English farmers are making extensive application of liquid manures. They apply them largely diluted, and the effects may be due, in some measure, to the quantity of water in which they are dissolved.

Liquid manures may be applied so strong as to injure tender plants. It is well known that gnano applied directly to the germinating seed, operates as a caustic upon its softened substance, and entirely prevents its growth. The same thing is true of ashes and lime under certain circumstances, and it is also true of urine; for when this is applied in large quantity, upon young and tender grass, it will often kill it entirely. 'There is no doubt that the English mode of application is much the safest, but in order to attain the same result, the labor is much increased; and we are hardly prepared to believe that the fertilizing power is increased in proportion to the dilution, as is said to be the case with the medicinal power of homœopathic medicines. Within certain limits, the immediate effects of fertilizer's may be, and doubtless are increased by dilution. The particles of soluble bodies are more finely subdivided, and are more readily taken up by the radicles of plants, and carried into the circulation. Indeed, this is doubtless the principal reason why liquid manures are more immediately active than solid. Water must always be present to render manure of any kind effective. Potash, lime, soda and all other salts, must be in a state of solution, before they can be absorbed by the rootlets of plants. Horticulturists well understand that all such substances can be applied with more immediate effect, in a state of free solution. Such substances, applied in a solid form to the soil, in a season of drought, have little or no effect, until the falling rain dissolves them, when they will sometimes operate with almost magical effect. Guano applied as a top-dressing, is sometimes almost wholly inoperative, unless the application is followed by rain. Hence, when this fertilizer is applied in this way, it should be applied in the early spring, while the ground is still wet, or during a rain, or upon an April snow, in order that it may be dissolved and carried into the ground, and thus be protected from the atmosphere, as well as be applied to the roots of the grass and grain. There can be no doubt that lime and ashes applied in the form of lime-water and weak lye, would be more immediately efficreious, than when applied in the ordinary way. But it would be attended with more labor and expense. How far this mode of applying manures will be found economical in this State, where labor absorbs so large a part of the working capital of the cultivator, each must judge for himself. 
Our own opinion is, that with the exception of urine from the stable and the house, which may be easily saved, and which is apt to be lost, in great measure at least, by any other mode of management, the application of liquid manures will be confined chiefly to the garden. For garden uses, soap-suds and the sewage of the house is usually sufficient to fertilize a garden that will supply the fumily with vegetables. All the liquids from the house should be conducted to a reservoir. A garden-engine, or a hand water-cart, with a few feet of hose and a sprinkler attached to it, will afford all the machinery needed. The soil may be well sprinkled before the seed is sown, and at snch times subsequently, during the growing season, as may be convenient or necessary. A little practice will soon teach the needful skill in the application. If plaster or a solution of sulphate of iron is occasionally added to the reservoir, it will both act as a deodorizer, and add to the efficacy of the manure. Much excellent manure might be prepared in this way, if every farmer, and every family cultivating a garden, would take the pains necessary to provide a suitable reservoir. The material that now runs to waste, and is, for the most part, a nuisance around our premises, might thus be made to add no inconsiderable amount to the products of our soil. Every fannily in a country town of tive hundred fumilies, might save manure to the amount of five dollars annually. 'This woukd amount to twenty.five hundred dollars, or one dollar for each individual in town. This would be sufficient to pay the highway tax, and build one good schoolhouse every year; or it would pay the entire school tax of most towns of that number of inlabitants. This amount of manure, properly applied, would produce five thousand bushels of corn or vegetables of equal value. If such would be the value of this saving to a single town of five hundred families, the value to the whole State would be a very large sum.

In our discussion thus far, we have had direct reference to natural manures, but we have introduced several observations relating to the composition and use of artificial manures. Most of these manures, as they are received from the manufactories, need little or no preparation, but are ready to be applied directly to the soil, or to be composted with other manures, or to he dissolved for use in a liquid form. It is not probable that they can be economically prepared, except upon a large scale, at establishments erected for the special purpose, and by machinery suited to the manipulations to which the ingredients are to be subjected. Superphosphate of lime consists of ground bones, supplied with an additional dose of oxygen by menns of sulphuric acid and water. Bloorl manures consist of blowd and animal fibre deodorized by substances capable of absorbing their nitrogen, sulphuretted hydrogen and moisture. Muriate of lime is either the waste of bleacheries, or more commonly, burned shells or quicklime treated with sea water, which imparts to the lime its salts, and a certain amount of muriatic acid. But as the furmer will not be likely to undertake the preparation of these and similar manures upon his own premises, it is unnecessary to go into a description of the machinery or processes used in their manufacture. 


\section{Tire Application of Manures.}

We have already said so much upon the application of manures, while treating of their preparation, that the reader will very naturally expect, and probably hope that this division of our subject will be very briefly disposed of. But before giving any directions respecting the application of manures, we must first institute an inquiry into the effects produced by mantures upon growing vegetables, and upon the soil.

Were the theory correct, that vegetables derive all their nutriment from the atmosphere, the application of manures to the soil would be of no advantage to them, unless it were to stimulate them to drink up the carbonic acid and the hydrogen, and in some cases the nitrogen of the atmosphere, more eagerly. But experience everywhere teaches us, that the free application of manures causes vegetables to grow with much more vigor, and to attain a much more perfect development. The obrious inference from this fact is, that manures furnish to plants the elements of nutrition, which they eagerly devour, and appropriate to their growtl. We know that in animals the food is received into the stomach, where it undergoes a sort of solution, and is then carried forward into the intestines, where it is presented to the mouths of myriads of little vessels, which drink up the fluid portion, and convey it to larger vessels, by which it is conveyed to the heart. 'Then by the heart, it is sent into the lungs, where it is acted upon by the air, in the lung-cells, and is then returned to the heart, and by means of the arteries, sent to the various tissue-forming ressels throughout the body. The blood in the arteries is apparently a lomogeneous fluid, but is in fact, a very compound fluid, containing in solution, various elements that previously existed in the food. The tissue-forming or assimilating vessels are endowed with the wonderful power of selecting from the compound mass presented to them, such elements as they need for their respective purposes, and of rejecting the remainder. From the materials selected, they build their several structures, and repair the waste that is constantly going on in them. Thus one set of vessels forms bone, another museular fibre, another skin, another bair, \&c. Other vessels fiom the same circulating fluid, eliminate the various fluids contained in the body, as serum, milk, urine, \&c. We know also that a circulating system in many respects similar, exists in vegetables, and that fluids drunk in by the hair-like radicles by which their roots are covered, are conreyed upward, in ressels arranged for this special purpose, and that when they have passed through the trunk, they are distributed to the leaves. The fluid passing upward from the spongioles to the leaves, is called the ascending sap. In the leaf, the sap is acted upon by the elements contained in the atmosphere. It then becomes the descending sap, and is presented to the various tissue-forming vessels in all parts of regetables. It is now apparently homogeneous, but in truth exceedingly compound, containing the various bodies in solution, which were drunk up by the radicles, and which have been absorbed from the atmosphere, by the leaves. 
The ressels of vegetables hare the same wonderful, and seemingly intelligent power of selection, that exists in the ressels of animals. They are thus enabled to select from the compound circulating sap, what each set of vessels requires, to construct the tissue which each has in charge. One set selects materials for the alburnum, another for the bark, another for the leaf and the leaf-bud; another forms the fruit-bud, and ultimately builds up the fruit. One set constructs the woody fibre, another set the starch, another the gum, another the resin, another the bitter principle, another the sweet and nutritious juices, another the poisonous elements. One set forms from the sap, the coloring matter that blushes or glows in the petals of the flowers, and the coverings of the fruit. Another selects, atom by atom, the lime that enters into the composition of the grain of wheat; another set weaves the covering for this same grain, from the woody fibre. Another set deposits the fatty elements, and arranges them in layers, around the starch and sugar and lime, of which the kernel of corn is built up. Thus every tissue and every prorluct of vegetable life, are formed by innumerable vessels, from the descending sap.

This sil] must contain, then, all the elements required to form all the various vegetable tissues, and for their rapid and perfect development,-the supply must be abundant-must be in due proportion, and must be furnished at the time when it is required by the formative vessels. An animal fed upon sugar alone or upon starch alone, will soon starve and die. The various vessels cannot obtain the materials necessary to carry on their work. So if a plant is furnished with only one element of nutrition, it will cease to thrive, or at least, only those vessels that are supplied by this element, will carry on their proper work. For example, certain vegetables supplied with an abundance of nitrogenous manure, will produce an exuberant growth of woody fibre-of stalk-of leaf; and but little or no fruit or seed.

We are now prepared to understand somewhat more clearly the effects of manures upon vegetable growth.

And first-manures furnish to the sap-vessels the various elements which they need for the construction of the various vegetable tissues, in such a state of minute subdivision, that they can take up atom by atom, what each requires. All the elements existing in the soil, furnish their respective quotas to the compound substance constituting the sap. Some of these elements are capable of solution in the water in the soil. Others are incapable of direct solution, and without the presence of some other element capable of either acting upon them, and thus rendering them soluble, or of combining with the solvent, and imparting to it a higher power of solution, they would remain inert in the soil. Thus silex is insoluble in simple water, but the presence of lime or potash in the solvent, gives rise to a new action, and silicate of lime or potash is formed, which is soluble, and thus becomes an ingredient in the sap. Silex is an important constituent in the epidermis of several of the grasses, and of the straw of grain, and the stalk of corn. When such plants do not contain a suflicient supply of silex in their outer costs, they break down under their own weight, and lodge on the ground, before they have attained their full 
growth. This we often witness in clover and herds-grass, and oats, upon reelaimed meadows and swamps. In such cases, a top-dressing of sand or gravel will impart to the growing stalk, the next season, suflicient hardness to enable it to stand erect, until its growtl is completed. In such eases, even if lime and potash are not directly essential to the growth of plants, they contribute indirectly an important service. 'This instance affords a beantiful illustration of the chenical aetion that is constantly going on in the soil.

Different soils require different treatment. Clay soils should be treated with lime, ashes, and light composts; such as contain straw and partially decomposed vegetable matters, keep such soils light, and furnish, by their decomposition, the humus in which they are deficient. Black, moist soils, that have been long cultivated, are generally exhausted of the lime and silex needed for grass and grain crops. Hence compost containing sand is especially useful on such soils. Lime may be applied freely upon the surfice of such soils, in the form of slaked lime, plaster, or superphosphate, with advantage. On light; sandy soils, well worked eomposts, rendered as fine as possible, and containing a large proportion of muck or other earbonaceous substances, and animal manures, of all sorts, are peculiarly appropriate. The influence of animal manures upon sandy soils, is well illustrated by the growth of corn and melons upon the sands of Cape Cod, by means of fish offal, and prepared fish manures. Such soils are hungry for the elements which these manures contain. Whatever manures are applied to sueh soils, should be well mixed with the soil, and well covered in.

Should manures be deeply covered in the soil, or should they be applied near the surface, are questions about which cultivators differ. 'The depth to which manures should be covered, will depend upon three circumstances, the nature of the soil, the kind of manure, and the kind of crop. All manures should be placed at a sufficient depth in the soil to keep them moist, or they will be inactive. When a soil is naturally moist and heavy, it is not necessary to bury manure as deep, to insure its being kept in a moist state, as when it is light and dry. Manures containing a large proportion of volatile elements, should be buried deeply. These elements, when the soil becomes warm, assume the gaseous form, and tend to rise to the surface, and will be diffused through the soil lying over them, and, if there are elements in the soil liaving an affinity for them, will be retained. Other elements, which are not volatile, as lime, ashes, salt, \&ce, but which are soluble in water, may be safely applied on or near the surface, and will be dissolved by the rain, and earried into the soil. Some vegetables strike their roots deeply into the soil, and for their perfect development require a deep tilth. In such instances, trenching is peculiarly advantageous. For such erops, manures should be worked as deeply as possible. In preparing a garden soil, it is good practice, to spread on the surface a coating of manure, and plough it in deeply, and then to add a dressing of fine compost or liquid manure, and work it in with the harrow or rake; thus the plant will find nutriment at every stage of its growth. For potatoes, it is not necessary to bury the manure so deeply, as they grow near the surface. 
The same is true of the flat turnip. The question has been often asked. how can manure be best applied for the corn crop; - shall it all be put upon the soil before ploughing, and be ploughed in deeply, or shall a portion of it be applied in the liill, or near the surface? When corn is to be grown on newly turned grass land, shall the manure be spread upon the grass, and turned under the sod? 'This is certainly the easiest way of applying it, and many contend that when it is applied in this way, although the corn may not be as vigorous in the early part of the season, yet in the latter part, when the roots have struck through the rotting sod, and found the manure deposited beneath, it will grow with sufficient vigor to make up for the time lost in the early part of the season. Others contend that it is better to turn over the soil in the autumn, and in the spring work in the manure upon the surface of the furrows, with the harrow or cultivator. In this way, it is said the corn will get a vigorous start in the early season, and when its roots strike into the mellow sod, they will find nourishment sufficient to sustain their growth.

In answer to both these positions, we reply, that the largest growth of corn that we have ever seen, was produced by a combination of the two methods. Two-thirds of the manure, say sixteen loads to the acre, were spread upon the sward, in the spring. 'This was then turned over to a good depth. The harrow was vigorously applied, and after this, furrows were made for the rows with a light plough. 'Then the other third, say eight loads, was put into the furrows and the kernels dropped ten inches apart. This gave the corn an early start, and it grew vigorously firom the commencement, and its roots soon found the rich nutriment deposited below the sod. The crop in this ease was one hundred and four bushels to the acre.

Practical men differ about the proper mode of applying manures in the culture of corn. As the corn crop is perhaps the most important crop to the country-is in fact the national erop, this is a subject of great importance. But it is questionable whether any rule of universal application can be given. We think that different soils maly require different methods of application.

In a clayey, heary soil, it is important that the management should be such as to render the whole soil warm and light. 'l'o accumplish this end, a large portion of the manure should be incorporated with the soil by the plough. We think green manures on soils of this description should be used for this purpose. libut as this soil, unless underdrained, is cold, and does not set the crop forward early, something more is needed. A small quantity of well composted manure in the hill, meets this deficiency. 'This process is attended with labor' and expense, but we think these are fully repaid by the result. Indeed in such soils, without the use of such means, the crop is uncertain unless the season is favorable. In light, warm soils, the whole of the manure may be worked into the soil with safety, and perhaps with more advantage to the soil, if the object is to prepare it for future crops. In any soil, if the chief purpose is to improve it, and preprare it for grass, grain or other crops, as speedily as possible, and the eorn crop is a secondary object, the whole anount of barn manure should be thoroughly incorporated with the soil, and a little guano or 
other nitrogenous manure put into the hill, to serve as a stimulus to the corn clop. In this way, when the soil is cold and tenacious, a good corn crop may be secured, and the soil rapidly prepared for future use. The stimulant will be expended on the corn crop, and will contribute little or nothing to the permanent improvement of the land. For this we must depend wholly, so far as manures are concerned, upon the stable and compost manures. But we think the corn crop is of sufficient importance to be considered a primary erop, and that the mode of applying the manure in all cases, should be such as to insure a good erop, while at the same time the permanent improvement of the soil is secured. 'These objects are by no means incompatible, and may both be attainerl at the same time, and by the same process. In the culture of corn, manures shoutd be liberally applied. There is less labor and less expense in raising sixty bushels of corn on one acre than on two, and in the former case the land will be left in a better condition than in the latter.

One great necessity for applying manure in our climate, is, that plants may be forced more rapidly through all the stages of their growth, since if left to themselves, the season would not be long enough to bring them to perfection; and that system of culture which pushes them forward early, that they may get well rooted, and theretore be the better able to endure the droughts of July and August, and thus arrive at early maturity, before the frosts of September, we think must be the best system. Could we add another month to the summer of our climate, we could cultivate many crops, with a much less amount of stimulants than we require at present. Now we have to guard against the droughts of summer, and the early frosts of autumn, and I do not esteem it safe practice, to deposit the manure for the corn so deep in the soil that the growing crops cannot reach it till late in the season. When stable manure or compost is ploughed in deep, we would recommend the application of well diluted guano ashes or fine compost in the hill. In this way, with a season at all favorable, the erop will rarely fail.

As a general rule, we would say that all compost should be well worked over in the early spring, before the weather becomes sufficiently warm to occasion a rapid development of the gases, and rendered as fine as possible. If the heap is too wet to work fine, a sufficient quantity of dry soil, or peat, or charcoal pulverized, or plaster should be added, to absorb the moisture and destroy the tenacity of the mass. All manures should be applied in as fine a state as is possible, without too much exposure to the action of the atmosphere. If manures are reduced in cool weather, when they are not in a state of active fermentation, it may be done without great loss of their gases. All manures that are to be applied to the surface should be pulverized as finely as possible. Some plants spread their roots near the surface, as the strawberry, and the whole family of the cucurbitacea. These especially require finely reduced manure. When manures are to be buried deeply in the soil, this mode of preparation is less absolutely necessary. All manures, whether applied in a coarse or fine state, should be immediately covered under the soil, that as much as possible of their volatile elements may be absorbed by the 
soil. These elements, as we have already said, permeate the soil, and divide its particles, and render them light and easily traversed by the delicate rootlets. This mechanical effect is one of no small importance. A soil rendered light and porous by fermenting manure, is as much better for the operation, as bread risen by yeast is better than a mass of dough.

It is the general practice of our cultivators to apply manures but once in the season. But certain manures may be applied more than once, with much profit, provided they are applied during the growing stage of the plants, and in such a form, as to mingle at once with the soil, and become a constituent part of it. It must be either finely pulverized or in a liquid state. In either form it should be immediately worked into the soil in the immediate vicinity of the plants, with the rake or hoe. Many plants, including most of the smaller fruits, may be treated in this way, with good results. We have already seen that manures may be applied several times during the season to grasses, thus enabling us to take two or three crops or cuttings in a year. This is of great value in soiling cattle, as it enables us to supply them with green and succulent food during the entire summer and autumn from the same ground.

Did we understand more perfectly the chemical constitution of all the plants which we cultivate, we might doubtless, in many cases, supply to the soil the elements especially needed by the plants. But we do not anticipate any very important results from the doctrine of specific manures, considered by itself. Grapes appropriate a large anount of lime and potash. Asparagus, a marine plant originally, appropriates marine salts. But we cannot depend upon lime and potash to give us luxuriant grapes, nor upon marine salts alone for large and succulent asparagus. They both require in addition to these substances, a generous supply of the same elements of nutrition that other plants require. Onr discussion has already prolonged itself much beyond our expectation, and we will not go into the subject of the application of this class of manures; and will merely remark that the subject is but imperfectly understood, and that much experimental research is needed to guide us in their application, to any certain results.

Nature works out from a few simple elements variously combined, the wonderful variety of products exhibited by vegetable life. If left to herself, she always obtains a supply of these elements. But when disturbed in her operations by short-sighted man, who removes from the soil its productions for his own use, instead of leaving them to decay where they grow, the soil becomes exhausted of necessary elements, and unless they are returned to it in the form of manures, she soon becomes unable to complete the processes which she commences, for want of material. The plant is not perfect. Its framework is not fully dereloped, or its seed does not reach a perfect form, or does not arrive at maturity. The crop becomes annually smaller, because the needful elements are annually diminishing. In the older Western States, we are told that the wheat crops luave diminished from one-fourth to one-third in quantity, per acre; and unless the elements that have been removed from the soil, are returned to it, the 
crop will contilue to diminish in a still more rapid ratio, until it ceases to be a remunerative crop. In Eastern Virginia and Maryland the soils that formerly yielded thirty bushels of wheat now yicld fire or six, and are being deserted because their prodsce will not sustain their cultivators. Guano has been applied to such soils. The nitrogen and phosphates and alkalies which it contains, render soluble certain elements still found in the soil; and one or two crops of ten or twelve bushels, have been taken fiom the soil. But this process will soon cease, and the soil be left more perfectly exliausted than before. Portions of this soil are being treated in a different way, by cultivators of market vegetables, who are applying muck, stable manure, lime, leached ashes, green crops, and whatever will restore to the soil, in the most permanent form, the elements required by such vegetables.

Hundreds of acres may now be found covered with thrifty crops of strawberries, gooseberries, currants, celery, radishes, turnips, beets, onions, melons, and similar crops, which a few years ago did not repay the labor of cultivation. The favorable climate and the convenient market render such cultiration highly remuneratire. The neighboring cities furnish the means of restoring to the soil the elements needed to sustain the large draught made upon it. The outlay for manures in this case is large, and for grain culture probably would not pay. But it shows in a striking manner what manures may accomplish. There is a vast amount of manurial substance produced in all cities, the largest part of which is annually wasted. If it could be carefully collected and judiciously applied to the soils in their vicinity, it would wonderfully increase their productiveness. But the transportation of manures to the soil to be cultivated, is an expensive operation, and will prove cconomical only within certain limits and for certain purposes. The true system of farming in this State is undoubtedly to consume upon the farm so much vegetable matter, that the solid and liquid animal excrement resulting, applied either simple or composted with other suitable materials, shall enable the farmer steadily to increase his crops, while at the same time, his soil shall be as steadily growing richer, and more productive. Every acre cultivated, should be left in better condition after the crop is taken off, than it was when it was put on. To attain this point, no more land should be cultivated, than can be done without exhausting it. The good teamster will keep his horses or oxen at work steadily, without diminishing their flesh or strength. Every one who has had experience will affirm that it is the most profitable to keep his team in high condition. The same thing is true of the soil. If the good teamster has food for only two horses, he will not attempt to keep three. So the judicious farmer will cultivate no more acres than he can feed well. In most instances it is better and more profitable, and attended with less labor, to raise sixty bushels of corn on one acre, than on two. 'The soil in the former acre is left in a better eondition, and in a better state for any succeeding crop than in the latter.

We think that in general, the farmers in this State must rely upon their own farms, for their permanent supply of manures. Imported manures and artificial manures may occasionally be resorted to, as 
temporary expedients. But unless the produce can be sold at a near market and a high price, their use will not be found economical in the long run. But although we think every farmer should rely upon his own farm, he may with propriety avail himself of such natural sources of supply as his own neighborhood affords. The cultivator upon the sea-shore may and ought to use the substances thrown at his feet by the waves. Fisl and tish offal are a resource of great value to those within its reach. If combined with peat as a deodoriz"r, during the process of putrefaction, it may be used without inconvenience. Marl beds are so many mines of wealth to cultivators in their neighborhood. In the vicinity of soap works, every one will be eager to avail himself of the leached ashes. 'The woolen factory aftords wool waste, an article of great value as a fertilizer. Various manufacturing establishments, as glue-making, tanning, gas-making, \&c., furnish waste material that may be obtained by furmers in their vicinity, at a remunerative price. Every opportunity to obtain these and similar materials, to acld to the nanure prepared in his own laboratory, will be improved by the enterprising farmer.

There is one other means of reclaiming and fertilizing an exhausted soil, to which we have barely alluded, which we think is worthy of more attention than it has of late received, especially upon light sandy soils, at a distance from the farm, or firom extra sources of supply, we mean the ploughing in of green erops. The best crops for this purpose are clover and buckwheat. Let the soil be ploughed fire or six inches deep, and seeded with buckwheat, early in the season; and in July, or as soon as it is in full blossom, let it be turned in, seren inches, and immediately seeded again, and it will give a second crop which may be ploughed in, in September. Let this be turned in, and clover sowed and harrowed in, and the next season this will afford a good dressing, which will prepare the soil for a crop of rye, which should be sowed in the latter part of August, or early in September. It' grass seed is sowed with the rye, lands thus treated will yield good pasturage, for three or four years, after the crop of rye is taken off, when the same process may be repeated. This process has been found an effectual means of restoring exhausted pine lands, and in cases where it is not preferred to renew the growth of wood, may be resorted to with economy and success.

We have now spoken of the principles which should guide us in the preparation and application of manures. We have also spoken of the elements which enter into the composition of the principal manures found in use in our State. 'The quantities of the several kinds which may be most protitably applied, must depend upon the circumstances of each case. 'These circumstances include the nature and condition of the soil, the kind of crop, and the character of the manure. When manures are carbonaceous and not volatile, they may be applied in large quantities at a time, and their effects will be permanent. When manures consist lar'gely of volatile elements, it is a better rule to apply annually or oftener, in such quantities as are needed for immediate effect. Such manures cannot be depended upon for the permanent improvement of the soil, for their active properties are soon converted into gases, and lost. 'Their power is expended in the 
growth of the present crop. Henee they should be applied only with reference to this crop, and in such quantities as its wants require. The quantity of any kind of manure must be determined by observation and experience. The judgment and skill of the farmer are to be his guides in this matter. There has been undoubtedly a disposition to cultivate ton much land,- to spread our manures over too large a surfice. When the soil was new, this answered tolerably well, and good crops were obtained for a time; but many of our farms have in this way become exhausted. As the soil becomes exhansted, by repeated eropping, of the fertilizing elements which had been stored up in it, the injurious effect of this treatment beeomes more and more apparent. Men are slow to renounce the usages that were established in former times, and under different circumstances. They hesitate to give up allegiance to custom, in agriculture, as in other things, and pursue practices of ruinous tendency merely because they are sanetioned by authority. Needed reformations are seldom inaugurated until they are compelled by neeessity. But many of our most intelligent cultivators have commenced the work of reform, and when we shall all, in every part of the State, so cultivate our lands that they shall become more fertile and more productive after every successive crop, we shatl have learned the only true and economical method of applying manures. 


[NEW SERIES. $]$

\author{
A \\ PRIZE ESSAY \\ ON
}

\title{
A G R I C U L T U R A L
}

\section{EDUCATION.}

\author{
BY \\ WILSON FLAGG, \\ OF ANDOVER, MASS.
}

B O S T O N :

1858 .

J. I. EASTBURN'S PRESS. 



\section{S S A Y.}

"The most useful system of agricultural instruction, by which to acquire a practical agricultural education, such us would fit a young man to commence the business of a farmer, upon the average of farming lands in Massachusetts."

IT will be assumed, at the commencement of this essay, that it is desirable that the farmers of Massachusetts shonld continue, as they are now, a class of independent working-men, and proprietors of the lands they occupy and cultivate. If we look about the country, we find indiriduals who own from one hundred to three hundred acres of land, who are industrious and able-bodied men, and intelligent citizens. They are capable town officers and good public servants in a variety of civil capacities. They are, also, proficient in practical agriculture, and are liberal and progressive in their ideas of their own business. Such men represent the standard to which we ought to strive to elevate the whole class of farm-proprietors. They should possess skill, hardihood and industry, because on these qualities depends their thrift; they should be well educated and intelligent, or they cannot preserve their independence.

There is no object, therefore, more deserving the attention of those who are directly, or indirectly, the guardians of the public interest, than the education of young men who are engaged in the pursuits of agriculture. At the outset, however, we are met by the objection, that the surest means of causing a young man to quit his paternal acres and enter into other business, is to give him a superior education. This is not to be regarded as proof that knowledge gives one a distaste for rural occupations, but rather, that it affords lim the capacity to earn a livelihood in an easier and more eligible way. A farmer's employments are laborious, comparatively unsocial and unstimulating to the ambition, and they do not lead rapidly to wealth. If, therefore, the son of a farmer has received a better education than the generality of his fellow-citizens, he leaves the farm, not always from a dislike to it, but, because he can more easily obtain wealth by the exercise of his wits, and by the use of his acquisitions, than by working in the field.

Men will not voluntarily pursue a laborious occupation, if their education and habits have fitted them for an intellectual or sedentary one which is attainable. Hence, if we qualify those young men who are to be devoted to agriculture, by a superior education, to earn an easy livelihood in some more eligible pursuit, we do that which will entice them away from the farm. Their attainments flatter them with at least the lope of success in other departments of business, and they will be led by this illusion to neglect, if not to leare their 
early chosen pursuit. But we are not to conclude from these circumstances, that this class of young men must be kept in ignorance; we are rather to infer that their education and discipline should be peculiar. Our present object, therefore, is to consider the means that could be most advantageously used for instructing young men in the science and practice of agriculture, without lessening their attachment to the occupations of the farm, or creating inducements for seeking their fortune in other ways.

In order to train young men to be good and persistent farmers, they must be better qualified to succeed in farming than in any other business; but we can only approximate towards any system of education devised for this purpose, and the greater number of its appliances must be indirect. If we cannot create agricultural schools and colleges; if we cannot, except to a very limited extent, furnish direct instruction to the youth of the rural classes - we may, nevertheless, supply them with new motives to make use of the opportunities they possess for acquiring knowledge ; we may inspire them with ambition to be skilful farmers, by making the farm their pride; we may induce them to put forth more energy in their occupation, by showing them how it may be made more profitable. Every young man is seized with a passion to become proficient in his business, as soon as he discovers that by skilful practice it may be made a source of wealth; while on the other hand, he cares not to learn or to pursue an employment which cannot afford him the gratification of his wishes.

It should be premised, if, indeed, it be not too obvious a principle to be mentioned, that the grand motive to follow any pursuit that requires patient labor and industry, while it holds out no tempting prizes to the ambition, is necessity. One obstacle to the improvement of agriculture in this country is undoubtedly the absence of an absolute necessity, on the part of any class of our inhabitants, to devote themselves permanently to farming. Neither has there existed an actual necessity for the exercise of a great deal of practical knowledge, or skill, in the occupation. When a farm has been exhausted of its fertility, the owner has perceived that it would be more profitable to sell the old farm and buy one that is new and unimpaired, than to endeavor to improve, or regenerate, the old one. The art of farming in America has been, to a great extent, that of buying and clearing new lands, and using the natural productiveness of the soil to the best advantage for the present time.

As population increases, and as the wild lands become exhausted, there will arise a necessity for the art of regenerating old farms and worn-out soils, instead of making the best present use of new and productive lands. This necessity has in a considerable degree already come upon the inhabitants of the Eastern States. But there are still so many avenues of employment open to young men, presenting them superior or more tempting inducements than the humble prizes which are offered by farming, that the growth of a strictly agricultural class must for many years be moderate. A young man will not consent to build stone wall or hoe corn in one field, while an adjoining one offers him an opportmity of digging for gold. The prosperity of agriculture would soon follow the concurrence of such circumstances 
as would render the business a matter of choice to those who were bred to it. By this we mean a state of things that should make it applarent to every intelligent young man who has learned farming, that he could not choose a wiser course for his own interest and happiness, than to devote himself entirely to this pursuit.

It is wise, however, to anticipate this period, and while millions of acres in the State are lying umimproved, to take such steps and use such ineasures as shall indıce a sufficient proportion of our youth to become good practical farmers, instead of seeking their fortune in the whirlpool of trade and manufactures. For the furtherance of this end, the most important requisite is to afford the younger portion of the rural classes such an education as shall so admirably fit them for agriculture, that their own pride in the excellence of their skill shall induce them to prefer it to other employments. Let us then consider the various appliances, direct and indirect, by the use of which we may gradually approximate towards the accomplishment of this desirable end.

In instituting a system of agricultural education, there are five general objects to be regarded :-

First, the moral training of the youth, to cause them to love their occupation :

Second, their physical training, to enable them to endure their labor:

Third, their mechanical practice, to fit them to perform their work :

Fourth, their early practical instruction to qualify them to understand their business:

Fifth, their instruction in collateral science to enable them to improve their practice.

The moral training of the youth, included in the first head, is the most difficult point to be discussed, under the present circumstances of the country, when other employments offer rnore dazzling temptations, and promise greater rewards than the sober occupations of agriculture. Population has not yet become so dense as to cause a man who owns a farm to congratulate himself that it is not other property. Indeed he often feels clagrined, when he considers that the accidental possession of a farm has imposed upon him some necessity to live on it. In too many instances a farmer with five or six sons is unable to induce one of them to remain upon the homestead and follow his occupation. All, one by one, as they approach manhood, leave the farm and give their attention to other pursuits. One learns a mechanical art, another studies a learned profession, and others become tradesmen. Not one can be persuaded to take the farm, though it be promised to him as his inheritance, if he will but consent to oceupy it.

We will admit that it is not desirable that every farmer's son should follow the business of his father. All other employments must be replenished by those who go out from the agricultural ranks, which must always furnish the largest proportion of healthy men. The aim of the statesman should be to place agriculture on such a basis, as that the father who is a farmer should always be represented by one 
of his sons, and that of several, the one who receives the farm as his portion, should be regarded as the most fortunate, though the others inherit the same amount of wealth; that the farm should not go a-begging for an occupant among the heirs; but should pass down from father to son, with all those advantages that attend the holding of an estate a long time in the possession of one family.

There are many causes for this general aversion to the steady pursuit of agriculture ; and in discussing the first point of a farmer's education, it may be well to enumerate some of the most prominent moral causes. The lesson that is tanght our young men is not, as it ought to be, to prepare themselves to obtain a good livelihood, and to practice that industry and economy which will slowly, but surely lead to competence : on the contrary, they are taught to look with secret contempt on one who would be satisfied with growing rich by the slow process of industry and frugality. A virtuous economy is not distinguished from avarice and meanness. Young men are led to overrate the importance of superfluous wealth, the hope of which absorbs nearly all their thoughts. The aims of ambition presented to their minds, are to be "great men:"-not inclustrious, honest and intelligent citizens-but men of excessive wealth or distinguished position -for such only receive the eulogies of the press, the pulpit and the lyceum.

If all the young men, who are destined to be farmers, conld be inspired with an ambition that is based upon the pursuit of agriculture, this ambition alone would cause them to become skilful and intelligent in the practice of their art. It is those who love their occupation who are the most likely to become well acquainted with it. The means and opportunities for the acquisition of knowledge are so great, that it is more important to increase the desire for any branch of knowledge than the opportunities for gaining it. But so long as young meu commence the business of farming, with an ambition only to be rich, they will not employ their minds upon the best modes of cultivation, but upon the means that might be used to cause a rise in the value of their estate. They will endeavor to get a railroad station near it, or some manufactory, not to improve the market for its products, but that they may convert the old homestead into houselots, and make money by the sale of them. Without denying that such enterprises may often be advantageous to the public, it is evident that this method of employing the mind is ruinous to the attainment of useful agricultural information or skill, and to the improvement of the farm.

This chance of growing rich by land speculation is very apt to ruin the thrift of a farmer, because it diverts his mind from his business, and employs his faculties in a way that does not increase his proficiency in his art. One is more likely by such efforts of the mind, to become a good politician than a good husbandman. Any train of circumstances, therefore, which serves to discourage these diverting hopes of wealth, and these speculating habits, and turn one's attention to the science and practice of agriculture, as his exclusive occupation, will prepare him for exeellence in his department. This must be a slow process, and must partly grow out of the changing condition of 
the country; it cannot be wholly the result of any direct system of training or instruction. But many influenees may still be brought to bear upon the public mind, which may serve to hasten the development of a general love for rural occupations, and an ambition among farmer's to be excellent in their business.

So long as our young men engage in farming against their free will and inclination, because they are crowded out of other paths; so long as, while occupied in the field, they comfort themselves with the hope that something may happen, which will turn the old homestead into a field for land speculation; so long as their ambition finds no gratification in the management of the farm, we would say, though they may be useful and intelligent citizens, they cannot be skilful or suecessful farmers. Some of the right ambition might be fostered by efforts that should induce men to improve the beauty of their farms. Many a youth might be prompted to retain the farm in his possession by that love which was first created for it, by its picturesque appearances, and those charms that please the eye of a man of taste. Let the old farmers understand, that if they would induce one or more of their sons to follow their occupation, they would find it expedient to avoid marring the beauty of their fields by the destruction of their natural ornaments. The removal of an old oak tree from a knoll in an adjoining pasture, or a fine clump of native shrubbery from the brow of a liill that overlooks the house, may turn the mind of the only one of the sons who has any inclination for farming, into another direction. Who can tell how many good resolutions, in favor of rural pursuits, have been destroyed by the axe that laid low the beautiful ash tree that shaded the path to the old farm-house, or the noble oak that showered its sweet acorns in some familiar nook! The avarice of the farmer who sells to the "timberer" the sylvan beauty of his estate, has made many an intelligent youth a voluntary exile from his paternal fields.

To make the farm an object of affection, it must also contribute something to gratify the desires of the ambition. A man who is proud of his farm would also wish to be proud of his farming. A taste for rural embellishment, prudently and economically directed; for that kind of embellishment which appeals to the principle of utility and to the love of nature rather than of art, may be made an important aid in improving the education of farmers. As soon as one begins to improve the appearance of his estate, he begins to improve his taste and his knowledge; and though he should spoil some things in his attempts, he becomes a gainer by the exercise which the work has afforded his mind.

It is somewhat dangerous to recommend home embellishments, as they are generally associated only with architectural follies, with nice gravel walks and showy parterres. The generality of men find it difficult to understand the meaning of embellishment, as applied to those simple and rustic ornaments that cost nothing, and which are so peculiarly appropriate to a farmer's home. The books which have been published in England and in this country, on "Landscape Gardening," furnish no valuable ideas to the New England Farmer, and the best of them would serve but to lead him astray. 
There are many other congenial influences that might be used to inspire young men with a love for rural pursuits. They are now too apt to consider their hard hands as disgraceful, and to overlook the honors which may be held in then. No man would be ashamed of his hard liands, who could point to certain results that prove them to have been intelligently employed. Let him show by his good practical information, his gentlemanly deportment, his excellent farm, his beautiful estate, and his happy and virtuous family-a subject as worthy the pride of an American as of a Roman-that his hard hands are associated with a superior intellect, and are proof that his mental gifts are not conjoined with physical degeneracy. Let him be proud of his possessions, not as mere evidences of wealth, but as proof's of industry, skill, intelligence and taste. How noble is such an ambition, compared with the wretched vanity of those, who sacrifice their manhood, and submit to the abject slavery of fashion, to gain a little short-lived notoriety.

Some beneficial effects might be produced by furnishing the town libraries with books that serve to raise the merits of rural pursuits. Books that aim, by the statement of agreeable facts, not by mere declamatory praises, to exalt our ideas of a farmer's life, and to render it pleasing both to the ambition and the imagination of youth, should be selected for the juvenile libraries. If no such works exist, they ought to be written. This is one of the neglected departments of literature ; for the praises which Virgil and Horace bestowed upon a country life, are in the present age considered as mere poetical fictions. The counting-room, not the open ficld, is now lauded as the situation most becoming a freeman. The slavery of confinement is preferred to the wearisomeness of labor, and men who were formerly taught to venerate the plough have forgotten their ancient faith, and have turned to a new worship.

We must not omit to speak of the improvement of household econorny, as likely to cherish a love for farming occupations. We introduce this subject in connection with what we have said on moral training, because the comforts and luxuries of home within the house, must exert an important influence in making one contented with his employments in the field. The table, no less than the fireside, should furnish a rational entertainment to the family, to fill the minds of the different members with agreeable anticipations, when they are away from home, and with cheerful satisfaction, when they arrive. If young men were accustomed to associate the farmer's life with all the wholesome luxuries of an ample and generous board, they would hold it in higher esteem, as well as affection. But if it is associated with the idea of a mean, unwholesome and monotonous fare, such as we see upon many farmers' tables, it is hated and despised. Our farmers' wives know less of the art of preparing culinary fruits and vegetables, in a variety of ways, than the people who live in town. Strange as it may seem, they understand the confectioner's art better than they know how to prepare for the table the simple products of the farm! A farmer's fare is exceedingly monotonous, and is far from being a model in regard to wholesomeness or economy. A little tract giving an account of all important vegetables and annual firuits, which may 
be raised for domestic use, the method of cultivating them, and the art of preparing them for the table, ought to be published and circulated among firmers.

We will conclude our remarks under the first general head, by alluding to the establishment of frequent periodical fairs, in order to supply the want of social pleasures, eonsequent upon the isolated charaeter of a farmer's home. This want of society is a sad misfortune, in many eases, and contributes, perhaps as much as any other circumstanee, towards creating a dislike for the occupations of agriculture. It is a want, however, which will gradually be supplied by the increase of population, and the multiplied facilities of travelling; but it may also be relieved by many expedients, which would indireetly aid the cause of education. Such would be the influence of monthly agricultural fairs in the several counties or districts.

We will now turn our attention to the physical training which is necessary to enable the young men to endure their labor. A boy who is to be a farmer, and who is expeeted to work with his own hands, must from his earliest years be trained to robust exercises. He must be educated in sueh a manner, as not to be incapaeitated to endure the toil and hardship of a farmer's life. Without this hardihood his business would be a sore afflietion, and not an agreeable and healthful employment. Labor and practice must attend all his steps; and a knowledge of the applieation of science to agrieulture must be imparted to him during those days and hours, when oceasion requires a suspension of labor. All the gifts of science which a young man can thus obtain, without a relinquishment of those habits of invigorating exercise, which are needful to insure a eapacity for toil, are clear gain to agrieulture. For every art, the youth who is to be instructed in it, must be trained in harness; and the knowledge that comes to him while handling the implements of his art, is worth more than the same amount gathered in a library. A slavish eontinuance of labor ought to be eondemned, beeause every man has a right to the enjoyment of life; but there is always danger, lest during long and frequent relaxations from labor, a young man may lose, both his eapacity to endure and his willingness to follow a toilsome occupation. Such an objection is very generally urged by our farmers against agricultural colleges, which they say, would not only unfit the youth for labor, but would cause them to turn away into other paths.

But our people obtain their ideas of an agricultural college from the customs of our literary institutions, in which there is no just provision for the physical training of the pupils. In an agricultural sehool, this would form a very important part of the exercises; and at such an institution, under a good system of regulations and diseipline, as at a military school, the boys would be hardened by their labor on the farm eonneeted with the school, while they were pursuing a course of studies. But agrieultural colleges must be slow in coming into existence, and under the most favoralile auspices, could not extend their benefits very widely anong our seattered farming population. Without denying the advantages which would accrue to those who should receive their education at such a school, we must at pres. 
ent consider how we can make the best use of the means of education which are available.

We must not overlook the fact that the farmer, unless he be possessed of great wealth, must be a working-man. He is not obliged to be a drudge; he may consistently with his robust frame and his laborious habits, be a man of extensive knowledge and an intelligent citizen; but he cannot be a student, in the usual acceptation of the term; nor a searcher of libraries. Like a soldier, he must be trained to robust exercises; he must be able to endure severe occasional toil, and must be preserved from physical degeneracy. Men of sedentary habits may be powerful in sudden efforts of strength; but the laborious alone can endure long continued exertion.

Excellence in any calling, or profession, cannot be attained without the entire devotion to it of all one's faculties. If we wish to convert our farmers into an aristocracy of landlords, a body of country squires, who shall merely superintend the operations of the farm, the physical training required by a laboring farmer, might in their case, be omitted. But they must not only enjoy increased advantages of education, they must also increase their wealth, by making it at least ten-fold greater than it is at present. It would be nothing to such a body of farmers, whether they could hold a plough or swing a scythe; nothing to them that they could not perform half a day's labor, nor bear exposure to cold and storm. Such a class of men, however, does not exist in the New England States. Our farmers in general are men who have but little wealth, except their houses and lands; and the amount of labor they can afford to hire is very inconsiderable. Out of these it would not be possible, if it were desired, to create a class of wealthy men of leisure. The aim of the statesman should be to improve the intelligence and practical skill of our present yeomanry, without inducing less industrious or laborious habits. The only cases we should except are of those individuals, who from ignorance and the want of sufficiently liberal ideas, have become voluntary drudges, and wear themselves out with excessive toil.

Superior intelligence, caused by the diffusion of knowledge among the mass of farmers, would probably diminish the necessity for the present amount of labor to produce the same results, since knowledge is confessedly one of the most important means to increase the efticiency of labor. Too many of our farmers are now mere drudges, and their wives and daughters are the same. This is the fact, in many instances, in which poverty cannot be pleaded as an excuse for it, and when it is plainly the result of ignorance, meanness or stupidity. It is a misfortune to be doomed to such excessive and unremitting toil, as to be disqualified for any exercise of the intellect, or for social recreations. This is the misfortune of some of the peasantry of Europe; but our people ought to be ashamed of it, because it is not their doom. Slavish toil is disgraceful to freemen, and produces both physical and mental degeneracy, by wearing out the body, and causing the faculties of the mind to pine away from disuse. We should endeavor to raise this class of our farmers from their present voluntary servitude, by extending to them the means of education. After they have become intelligent men, they will be thrifty farmers, 
without degrading themselres to the condition of beasts of burden. Acknowledging the dignity of labor, when it is guided by intellect, we should endeavor to convert our farmers into a superior class of working-men.

The Americans are probably excelled by Europeans in the capacity to endure severe labor and hardship. This is not the effect of our climate, but of the changeful and unsystematic habits of our rural population, with respect to labor and exposure to the vicissitudes of the weather. Few of our farmers have always been steady in one pursuit. Farmers' boys are generally vacillating between shoemaking and farming, during all their early years, and sometimes for the greater part of their life. They frequently pursue the two occupations together, being shoemakers in the winter, and farmers at other seasons. Such a course may have been promotive of their interest, under the past circumstances of the country. But the sedentary and confined habits of the shoemaker are enfeebling, and a shoemaking farmer, other things being equal, cannot be so robust and so capable of enduring protracted labor and exposure, as one who has always confined himself to the exercises of the farm. One may be somewhat more intelligent on general subjects, if he has joined his occupation with other pursuits; but his practical skill in agriculture must be somewhat diminished by the same causes. We cannot have an agricultural population equal in practical skill and efficiency to that of the best agricultural provinces of Europe, until a change of circumstances has caused our farmers to be exclusively devoted to their art. So long as farm-labor is so unsystematic, that during a considerable part of the year, a farmer must attend to other business to fill his unoccupied time, agriculture cannot be carried to perfection.

While treating of the capacity for enduring labor and hardship, as an indispensable qualification for a working farmer, the question naturally arises, how far an individual may cultivate his mind without enervating his body. This is an important physiological inquiry; for it is granted that the highest cultivation should be recommended to every class of working-men which is compatible with the requisite amount of muscle and physical energy. But there is a law of compensation, which it is unwise either to ignore or to overlook, how much soever it may disturb our ideas and hopes of human perfectibility. While it will not be denied that the best system of eaucation, for any class of people, is that which permits none of the physical, moral or intellectual powers to remain unimproved, it must be admitted - however deeply we may regret that nature has established such a law - that any amount of time or exertion which is devoted to an intellectual pursuit, is subtracted from the time and exertion which might be employed in hardening the muscles, and fortifying the health. While we are cultivating our faculties for a certain class of exercises, we are sacrificing so much of our opportunity, not to say our ability, to acquire skill in exercises of an opposite character. Hence the notorious fact, that the most thrifty men, in the common ranks of life, are those who are fitted only for one occupation, if that one is their own special calling. A want of versatility is favorable to success, in the case of all who have learned and adopted a profitable business. Those 
who are ignorant of all arts except their own, have no temptation to turn aside from it. They do not yearn for a more agreeable and congenial exercise of their faculties, like one of superior talents who would see many other ways in which he might be more pleasantly, if not more profitably employed.

We will not pursue this analysis any further, but hasten to the conclusion, that a different system of physical, moral and intellectual training is needful, respectively, for the members of the different trades and professions. If we train a merchant to be a philosopher, though we may increase his usefulness to society, we spoil his chance of becoming rich. If we inoculate a mechanic with a knowledge of the law, he becomes more skilful in disputation than in the use of tools. If we convert a farmer into a book-worm, his conversation is likely to be superior to his practice, and his head becomes stronger than his hands. The educational question, which has not yet received a satisfactory answer, relates to the course of training and instruction which will serve in the best manner to improve the rural classes in knowledge, and give them, at the same time, the greatest efficiency as agricultural producers. It seems to be very generally admitted, however, that they should learn by practical observation and occasional reading, rather than by any regular devotion to the study of books.

We are not prepared to contend for that severe application to toil that leaves no time for recreation, or for the acquisition of knowledge; but merely for that regular devotion to robust exercises which is necessary to preserve the greatest vigor of the physical constitution. Our rural population must be preserved from physical degeneracy, or as a nation we are lost; for it is on this class that we are to depend for the constant re-inforcement of the other ranks of society. We can place no such dependence on the great body of artisans and mechanics, since the majority of the mechanical arts tend, more or less injuriously, to cramp one set of muscles and to orertask another set. It is not among mechanics or the learned professions, that we are to look for the most complete amount of physical development. Many of the mechanical occupations are of such a sedentary character, and so partial in their exercise of the frame, as to deform the body and seriously impair the constitutional vigor. This cannot be said of the employments of the farm. The sons of farmers, if brought up to agricultural labor, are, above the children of all other classes, likely to become good models of sound physical men. Their employments exercise about equally all parts of their body : there is not a limb or a muscle that is not continually brought into action. If our farmers, at the present time, do not exhibit such a completeness of development, it is because in connection with farming, they have pursued other occupations which are less healthful, or they have committed certain essential errors of diet and regimen, which are very common among our laboring classes.

When employed, therefore, in devising a system of agricultural education, we must not overlook the necessity of preserving the rural classes from physical degeneracy. It is better that they should be less scientific than less robust, less studious than less healthful : better that they should be good farmers by rote, than effeminate scholars 
who are unable to work. It is not probable that any action of our agricultural societies can revolutionise the labits of our rural population; but without doubt a succession of wiscly directed efforts might set in motion a reformatory action, that would gradually elcvate this class to the point which should be the end and aim of a rational philanthropist.

In studying these effects, we must not forget the influence of opinions which, in their action on the general mind, when first introduced, are like alterative medicines to the human system. If we can but succeed in infusing correct opinions into the minds of men, these ideas will cause them to do for themselves what a wise ruler might wish to do for them, by the establishment of good institutions. The rural classes have been greatly prejudiced against the improvement of their minds, by hearing too much said in favor of scientific attainments for the farmer. Their common-sense inclines them to believe that there is more cant than philosophy in all this preaching. If we claim too much for science, in its application to agriculture, our audience may refuse to allow so much as they would, if our claims were less exorbitant. They perceive a certain incompatibility between study and labor, between hard muscles and a full mind ; and hence they are led to doubt the advantageous application of science to the exercise of their art. A contrary opinion must not be enforced upon them without qualifications ; for the common-sense of uninformed men is often right when philosophy is wrong.

Men must be taught in a way in which they are willing to receive instruction, and will not learn from those whose teaching humiliates them. A farmer is usually proud of his common-sense, of his bodily strength, his sagacity, his manual skill and his practical information. Though he may orer-estimate himself, he cannot too highly estimate these qualities, of which any man may reasonably be proud. If we approach one of these practical, sagacious and sturdy fellows, and humble him by trying to prove that he would be a better farmer, if he was likewise a man of science-a chemist, a botanist, an entomologist and philosopher-he is offended. He has a sort of intuitive understanding that such a combination of science, practical skill and robust vigor is impossible. The man who is trying to enforce upon him the value of science may state many undeniable truths, but he cannot convince him that a college would turn out so many good farmer's, among the same number of pupils, as an agricultural district, with the farm for the school-room, nature for the laboratory, and intelligent farmers for instructors.

The third division of our subject relates to the early mechanical practice which is required to fit young men to perform their work. The distinction between practical knowledge, and manual skill or mechanical tact, is not generally understood, but it is a very important one. The proprietor of a farm, who should superintend its operations, if he were young and capable, though he never joined in the labor, would soon obtain a practical knowledge of farming. But unless he participated in the labor, he would not learn to hold a plough, to swing a scythe, nor to perform any but the most simple operations of agriculture. He might be thorough in his practical 
knowledge, a good adviser in regard to times and seasons, sowing, reaping and all that appertains to successful practice. Still he is not a complete farmer, because he is wanting in manual skill and mechanical tact. He cannot with his own hands perform the manipulations of the farm.

An ignorant journeyman, on the other hand, who feels no particular interest in farming, except to perform satisfactorily those manual operations which are required of him as a hired laborer, such as ploughing, sowing, mowing and reaping, may be very deficient in practical knowledge, and incapable of managing a farm. The qualifications of each of these men must be joined in one to make a complete farmer. The first is a man of practical knowledge without mechanical tact, the other possesses mechanical tact without practical knowledge. Too many men who call themselves farmers are mere users of tools, efficient workmen under the direction of others, but wanting in that fund of intelligent experience which a master farmer must possess. In large manufactories, where there is necessarily a minute division of labor, it may be expedient to convert men into machines, each individual performing only his particular part of the work. But the farmer must be a whole man, not a machine; he needs to be both head and hand: he must have strength united with skill, skill with experience, and experience with intellect. Otherwise he is but the fraction of a farmer, and must depend on others, either for guidance or execution.

With regard to manual skill and practical knowledge, we would remark that there are more who would acquire the first than the last, under equal opportunities for becoming proficient in each, because an aptness to perform mechanical operations is a more common talent than an aptness for nice and intelligent observation. But it cannot be said that one is more important than the other. It is the practice of these manual operations that gives a man that complete physical development which is essential to a working farmer. One may learn how land should be ploughed, by looking on, while the ploughmen are at work; but if he only looks on, he loses two advantages: he fails to acquire that hardness and vigor of muscle which are developed by such exercise, and the mechanical skill and tact which are needful for performing the task. The same may be said of all the other exercises of the farm.

The farm must be the gymnasium in which strength and dexterity are acquired, and the school in which the agricultural art must be taught. Manual skill, like skill in debate, in mathematics, or in any exercise of the wits, can be acquired only by early practice. Science must be learned in college; music in the concert room, the art of war in the camp, and the practice of agriculture in the field. While an intelligent lad is working on a well-conducted farm, he learns more than we might at first believe: he is at the same time obtaining knowledge, hardihood and dexterity. If he is building wall, every stone he lifts from the ground hardens and perfects the growth of his muscles, and every stone he places upon the wall accustoms him to the skilful adjustment of the different materials. While he is ploughing, he is acquainting himself with the character of different soils; and 
when engaged in weeding, though he is not a botanist, he learns to identify all the various plants that inhabit the soil. The fund of practical information thus obtained by capable men is not fully appreciated, nor is the public generally aware how many different uses of the muscles are required by the common tasks of the farmer.

A physician or a merchant may resort to farming, and without the advantage of early practice, be remarkably successful in his new business; and the success of such individuals has led many persons to overrate science when compared with practical experience. But it will be found that these men are always dependent on the advice of some person who has, from his youth, been accustomed to farmlabor, and has become practically conversant with its exercises. WVere they left alone in their undertaking, or were they assisted only by others like themselves, they would make a sad failure. He who attempts, after his youth is past, without any previous experience, to carry on a farm, soon discovers, that notwithstanding his superiority to the mass of farmers in his capacity to learn new things, and in the power of judicious discrimination between the value of new and old systems, he suffers a painful inferiority, in minute practical knowledge, to the most ordinary laboring man who was bred upon a farm. Men who leave the ranks of a profession, or a counting-room, to become farmers, and who, on account of their more liberal ideas, obtain many important advantages over the old practitioners, do not always sufficiently consider how poorly their education would serve them, if there were no practical farmer to advise them, nor skilful workman to perform their labor.

Some may be disposed to deny that the manipulations of the farm require that long apprenticeship which is usually devoted to learning a mechanical art. This may be true of any particular branch of farm-work; but there is a great variety of labor and skill involved in the whole circle of operations. A young man who is strong and capable, may learn in one season to swing a scythe, so as to be reckoned competent to receive ordinary wages; but an experienced mower would readily perceive his own superiority. If, however, he could perfect himself in one set of manipulations during the first season, he would require a second season to learn another set, and before he was proficient in all departments of skill, he would have served nearly a seven-years' apprenticeship.

It is worthy of remark, that while men in general see very clearly that they cannot be good practitioners of certain arts, without a long course of study and experience, they believe that there are other arts which they would not be obliged to learn, but may, if they please, "take up," at any time. One of the occupations which they suppose they can "take up" thus suddenly and without preparation, is farming. When they watch an artist who is drawing the working-plan of a house, in all its parts, they perceive, if they are not artists, that he is performing a work which is beyond their own ability; but when they see a man dropping potatoes into a hill, or hoeing up weeds, they think they see the evidence that any one can be a farmer. The practice of agriculture and the practice of medicine resemble one another in this indistinctness of their requirements; yet they are the 
most difficult of all arts, because there are so many circumstances in their experience, which cannot be precisely stated or exactly defined. Hence there are multitudes of stupid and ignorant persons, who believe they can successfully act the farmer or the physician, because they are incapable of seeing or appreciating their deficiencies. With respect to mathematics, and all the exact sciences and arts, every man of common-sense, who is ignorant of them, understands the proof of his ignorance. A man sees at once why he cannot make a telescope, or survey a coast by trigonometry; but he cannot see why, if he has learned the virtues of a few herbs, and the names of a few diseases, he may not be a physician, or why, if he knows how to put seed into the ground and cover it up, he may not be a farmer. A science or art requires experience, in exact proportion to the uncertainty that exists in the application of its rules and principles; yet this very uncertainty renders the ignorant more bold in assuming the practice of such an art. Hence the multitude of quacks who invade the ranks of medicine and of agriculture.

A complete farmer will be found, therefore, only among those who were brought up to the business of farming. All others must be awkward in the performance of their labor, unskilful in their manipulations, imperfect in their practical knowledge, and if they carry on a farm, ean be successful only by using the advice and experience of their hired men. The operations of ploughing and scattering seed, of mowing, reaping, gathering and stacking the different crops; the rearing of animals and the management of cattle, both when employed in labor and when in the stall; the modes of executing the different tasks connected with their training, and the adjustment of their harness and their burdens; the care of fences and buildings and the preparation and equipment of agricultural implements, constitute a variety of performances, and require a manifold exercise of mechanical skill, which can be acquired only by many years of early practice.

To encourage this kind of practical skill and dexterity, it is evident that we must promote the growth of a class which is exclusively agricultural. We do not say caste, because this would imply a certain want of freedom to leave its ranks; and such a state of things is always fatal to improvement. All farmers' sons in this country are not expected to be farmers; it is sufficient that those who consent to be their representatives, should be trained from their early years with this expectation. 'The others are expected to constitute the best materials to replenish the ranks of other occupations. Our people have but little idea of the extreme nicety with which many of the operations of the farm are conducted by the rural classes of Europe, and which is the result of their exclusive attention to their art. This carefulness has never yet become a matter of absolute necessity in our system of agriculture; but the efficiency of labor depends greatly upon it, and it will become ere long indispensable to the farmer's thrift and success.

The next topic of our discourse on the education of farmers is the early practical instruction they require to enable them to understand their business. With regard to practical knowledge and manual skill 
in executing the tasks of labor, it would be very far from the truth to say that one might not be an excellent farmer with these two qualifications alone. Indeed, it would be diffieult to find a person who joined these qualifications with a proficiency in agricultural science, which is more generally possessed by those who may be called amateur farmers. Every man is not able to learn science in the midst of his necessary avocations, and there are not many who are born with the capacity to understand general principles. The majority of men, even when highly educated, must be governed by facts and dogmas. The mass of practitioners in the learned professions and the liberal arts, though possessed of deep learning, are mere matter-of-fact men and followers of routine, because every man is not born a philosopher. It is a good and efficient practice, therefore, which is needful to be inculeated upon the majority of every profession and calling. If we can but soften the prejudices and obduracy of farmers, that they may be willing to renounce their errors, to admit new facts and adopt new ways, we shall have attained the most important advantage for the furtherance of our ends.

We have chiefly confined our remarks to incidental means of instruction, but have not yet devised any systematic course of education in the agricultural art. If we ask farmers how a young man could be most properly instructed in this art, the answer which would be given, almost unanimously, would be-_"Put him on a farm with a capable farmer, who will set him at work, and he will learn. his business by practice and observation, joined with such instruction as he may receive from his master." Nothing could be more reasonable than such advice, under the best circumstances of agricultural practice, and it corresponds with all the precepts we have inculcated in this essay. The boy, if he equals his master in good habits and capacity, would probably become just such a farmer as his master; but if he obtained instruction from no other source, except his master's precept and example, he would not be likely to surpass him.

We are led, therefore, to inquire how the lad is to obtain that additional instruction which, under the present imperfect condition of American agriculture, the generality of farmers could not impart either by precept or example? It is admitted that the best school for agriculture is the farm, that the best teacher must be a farmer, and that practice is more important than study; but it does not follow from this admission, that every farm is a good school, nor that every farmer is a good teacher. It remains, therefore, to discover some means which may be successfully used to convert the generality of farms into good schools and to supply the farmers' deficiencies in the capacity of teachers. Shall something be annexed to each farm, or to each agricultural district to furnish that instruction which the present generation of farmers cannot impart; - shall agricultural schools be established to supply this want; or, lastly, shall it be supplied by the distribution of books and tracts, the diffusion of agricultural journals and the multiplication of lectures?

Let us first consider what sort of appendages might be made to the farm, or annexed to an agricultural district to answer these purposes 
of education. The adjuncts recommended by different writers and lecturers on the intellectual wants of agriculture, are reading-rooms, cabinets and libraries, and courses of lectures on the different departments of farming. With these are to be associated farmers' clubs, to meet at the reading-rooms, for the purposes of debating, conversation and study. To render them useful in the highest degree, the public would be invited to send curiosities and other useful and interesting matters to the cabinets, and individuals of other professions would be invited to participate in their discussions.

Each of these schemes would, as far as they are practicable, secure some of the purposes intended. But there are many obstacles that interfere with the general establishment of them. Associations of farmers cannot be instituted or maintained, like mechanics' associations, because the rural classes are scattered widely apart, while mechanics are congregated in towns and villages and can readily assemble. Farmers' clubs and associations, except in some highly favored districts, must assume the character of fairs, which may be held periodically for the exhibition, sale and purchase of agricultural products and live-stock. We have no doubt of the great benefits that would result from the establishment of clubs, reading-rooms, cabinets and lectures; but they cannot be extended or multiplied so as to meet the wants of the whole population. They must, even if they were numerous and general, be widely distant from the majority of those who would be expected to attend them. Nothing could be got up at these rooms and at these meetings, of sufficient interest to call tired laborers together, from their distant and isolated homes; and a very small number only would feel any lively concern in the object of such institutions. This last remark would not apply to periodical fairs, because the pecuniary interest of the parties would induce them to attend. Of these, their connection with the prosperity of agriculture, and their influence on the education of farmers, more will be said in another essay.

Theoretical attainments, and the knowledge of practical details may be said to exert in one respect an opposite influence on the mind of a pupil in agriculture. The first, carried beyond certain limits, would tend to divorce a young man from his business, and wed him to other pursuits more tempting to the ambition. Study not only disinclines, but partially incapacitates one to endure protracted or severe labor; and a speculative habit of mind is a bar to steady progress. But the greater one's proficiency in practice, the more closely is he bound to his pursuit; for, just in proportion as one feels conscious of his ability to excel others in the occupation to which he was bred, would be the strength of his motives to adhere to it. A man's ambition commonly lies in the path of his talents and acquisitions, and he will not forsake this path as long as it affords him a good livelihood. In regard to practical knowledge, therefore, the remark of Pope is strictly truethat " a little learning is a dangerous thing," because one's practical deficiencies would be fatal to his success. But in regard to theoretical knowledge, so far as it concerns the farmer, the maxim might be reversed; a little learning is useful, but more might destroy his inclination for the labor of a farm. 
It seems less difficult, however, to devise methods of communicating scientific than practical knowledge to the youth, beside that which they would learn on the farm. All those who are willing to read might learn the most important results of science from books and lectures; but practical details are not so easily communicated through such mediums, and inust be acquired chiefly by observation, experience, and verbal instruction while pursuing oue's avocations. The theory only of any art can be thoroughly taught in books. $\Lambda$ young man of good talents may learn from books the whole theory of banking and mercantile business; but if, without having been bred to the arts of banking and trade, he should attempt to practice them, he would find himself greatly inferior to many an ordinary person who was incapable of comprehending a general principle. Many an able writer on the economy of trade would make a miserable financier.

Still it will not be denied that a very considerable amount of practical information may be communicated by books and lectures. Our agricultural journals have been an important medium for the conveyance of practical knowledge as well as science. A book may exhibit the best methods of performing the different operations of grafting and budding, of transplanting, of draining, of constructing fences and buildings, of identifying and destroying injurious insects, and a variety of other matters which may be explained by words or illustrated by diagram. But there are many other things which cannot be stated with sufficient clearness in language. No man could learn from books to distinguish the different varieties of wood and timber by their grain and general appearance; or the marks by which an excellent animal is distinguished from one nearly as good - marks which are well understood by a farmer who is practically skilled in the physiognomy of domestic animals.

Many a person knows by experience those signs in the heavens that indicate what the weather may be for the two or three following hours; but, however excellent in description, he could not by words, without exemplification from nature, make others understand these signs. He must call them to him and show them the actual appearances; he must give them a portion of his own practical experience. Books cannot intelligibly define all the different marks by which a practical farmer distinguishes a good soil from a poor one, a calcareous from a siliceous soil, or a fresh soil from one that is worn out and exhausted. These marks are seen chiefly in their productions; and to explain them all in words would require long pages of details. But the experienced farmer reads them all at a glance, from the page of nature. On an exhausted soil he sees the starveling weeds coming up almost without foliage; grasses in meagre tufts half enveloped in moss; bindweeds with not strength enough to extend beyond a few inches fiom their roots; grey mosses, or jungermannia, appearing among a few feeble shoots of brambles and lycopodies, and an occasional grasshopper, that seems restless and discontented amidst the insufficient provision of nature for lis sustenance. It would be impossible to enumerate the marks of a worn-out soil, none of which a practical farmer ever mistakes; and though he may not be able to give 
a botanical name to a single one of these plants, he is no less accurate in his observation and his judgment.

An important step towards improving the rising generation in practical knowledge would be taken, if any way could be devised for teaching farmers in general the art of conveying their own ideas in words. This is not a common faculty: even those who have what is called the "gift of the gab," seldom possess it. With this power of explaining their ideas, less of the knowlelge which the masters possess would be lost to their apprentices. This object might be partially accomplished, by writing a practical farmer's own ideas in simple and intelligible language, and presenting them to him in print, for his perusal. By this perusal of his own knowledge it would assume a more palpable form, and a more distinct arrangement in his own head. He would "understand himself" better than he did before. Many persons of ordinary education but good practical sense, might be made capable instructors, by the aid thus afforded them. Independent of this advantage, a practical farmer would feel complimented by seeing his own thoughts clothed in expressive terms, and made clear to his understanding. There is many a farmer who can write the English language grammatically and with propriety, who would find himself greatly at a loss for expressions, to convey his thoughts distinctly to another's mind. Words are important aids to thought, and improve the clearness of our comprehension, as diagrams assist the pupil in geometry.

This course of reasoning would seem to indicate the advantage of publishing and distributing among farmers, short tracts on subjects of practical agriculture, after the system pursued by religious tract societies. These should not be thrust intrusively and unceremoniously upon the heads of families, but sent to them by their leave and under the general title of "Tracts on subjects connected with practical farming in New England, gathered from the experience of farmers, for the benefit of their youth." As means of instruction, these tracts would be more effective than the agricultural journals, we may say, without any disparagement of the latter. When one takes up a tract, if he reads it at all, he would read something that appertains to agriculture: whereas if he takes up a newspaper, the agricultural paragraphs might be the only parts which he would omit; and they are usually the parts to which the young reader pays the least attention. Besides, if the tract were published by a committee of an agricultural society, it would seldom put forth any important. errors; while the editor of a newspaper, however correct in his knowledge and judgment, is constrained to publish many crudities and whimsical notions to satisfy the vanity of his correspondents.

It is needless to enumerate the topics which might be discussed in a series of agricultural tracts. It is enough to say that they should be written in a simple and luminous style, that they should treat only of those matters which can be made interesting, and that they should be gratuitously distributed. When treating of science they should not be abstruse ; it is better to leave some important things unsaid, if they be so abstruse as to disincline the reader to continue to the end 
of the chapter. The tracts on scientific subjects ought, therefore, to be written by intelligent persons, who are not professors of seience, as the latter are notoriously incapable of rendering their ideas in popular language. Those of a practical description might be written by any one who has the command of an easy and perspicuous style, and who is sufficiently acquainted with agriculture, to make correct reports of the information he should obtain from its original sources.

An editor, who is capable of writing a part of the series, should be appointed to superintend the preparation and publication of the tracts, which might be distributed according to the following plan:-Let each County Agricultural Society in Massachusetts receive at the cost of paper and printing, as many copies as they might see fit to circulate among their fellow-citizens. The Massachusetts State Board of Agriculture might be responsible to the printer and publisher, and pay the editor's salary, as their part of the expense and trouble of the enterprise. The burden of distribution, and the publishers' cost of all they distribute, might fall upon the County Societies, as their part of the labor and expense. The tracts should be published monthly, in small duodecimo form, printed with long primer type, and containing about eight or ten pages. The cost of the publication would be too small to stand in the way of its expediency.

In the last division of our subject, we are to treat of the scientific instruction which is needful to farmers to enable them to improve their practice. A good and efficient practice must not be sacrificed, nor even jeopardised by application to the elements of scientific farming. Let the youth be thoroughly versed in all the branches of practical agriculture: it is sufficient, if they are only inoculated with science: the mind is cleared thereby of those vulgar humors called prejudices, which are the grand obstacles to progress and improvement. It is not desirable to convert farmers into men of science: their avocations will not permit them to aequire the learning of a professor : but they ought, as far as possible, to be made familiar with those important results of the investigations of learned men, which bear closely upon the interests of agriculture. Some of the discipline of science would also be valuable to them, by giving them an intelligent ear and a willingness to listen.

He may be considered therefore, a good scientific farmer, who is acquainted with the general results of science which are important to agriculture, though he may be ignorant of the processes that led to them. If, for example, one has learned the constituent properties of a good soil, though he may not be able to analyze it; if he knows why a plant is dependent on its foliage for its growth and development, though he cannot state the methods by which this fact may be proved; in fine, if one understands the general results of agricultural chemistry, though he is no chemist; the improvements in agricultural machinery, though he is no mechanician,- - he has all the science which is generally available to the farmer. More than this cannot be expected of those who devote the greater part of their time to labor, and who must acquire a large stock of information from experience, before they can establish themselves in business. 
The most unwilling learners are those who are proficient in a certain mode of practice, and who possess but little general knowledge. They perceive their own expertness in an art which but few understand as well as they do, and they have naturally become proud of their proficiency and jealous of those who attempt to instruct them. This sort of bigotry is the result of ignorance, but not the ignorance of one's business, and it is very eommon among good practical farmers. A little more general knowledge would give them a willingness to learn new ways, and to correct their errors. It is the obduracy of such men that causes them to jog along in the old by-road of professional routine, while the public is carried forward in the car of innovation. Hence we may account for the fact sometimes observed, that young men who leave the ranks of some other business and become farmers, go ahead of the old practitioners, in spite of their want of skill and practical knowledge.

One great desideratum, therefore, in agricultural education, is to gain a willing audience among practical farmers, and to show them, without wounding their pride, that there are many things to be learned by which they might improve their practice. A s!ight acquaintance with the facts of science tends to liberalize their mincls in this respect; and as soon as one has been converted into a willing listener, he cannot avoid becoming a learner. The streams of knowledge are pouring down the hills of science in a thousand different channels. They would spontaneously flow into every capable man's mind, if he would consent. But many of our farmers shut them out by positive efforts, lest they should disturb the sluggish waters of prejudice that form a charming landscape to their sight.

The public entertains no very distinct ideas in relation to the amount of seience which is required by the farmer for the improvement of his practice. The error of those who have treated of the subject consists in demanding a larger stock of information of this kind, than could by any means be rendered available to the generality of working-men. In regard to chemistry, it may be expedient that a farmer should know the chemical relations and affinities between acids and alkalies, between oxygen and metallic substances, and the results of their different combinations: he should understand the mutual dependence of the soil, of the atmosphere, of animals and of vegetation upon each other, and should know their constituent elements. All this he might learn, without deep study, from a little instruction in the grammar of chemistry, which ought, indeed, to be introduced into the distriet schools, being important to other arts beside that of the farmer. The grammar of chemistry would enable one to learn and understand many facts which are constantly presented to the observation of farmers, and are lost to them for the want of that rudimentary instruction that would make them intelligible.

Most people feel a sort of contempt for botany, as if it were only an amusement for young women, and not a grave study worthy of a man and a philosopher. They associate the study only with flowers, without considering that it has occupied the whole life of some of the 
greatest of men. Our horticulturists generally possess a good knowledge of botany ; and thongh it is not equally important to the farmer, it wonld greatly assist his progress in knowledge, and afford him many a pleasant exercise of his observation. A farmer should understand the general prineiples of classification, and should be able to ilentify a plant by a botanical description. How limited soever this knowledge, every new fact which he learns renders him more intelligent; and every new ray of science that enters lis mind, removes some film of bigotry that lias been drawn over his mental sight.

Let a young man understand the elements of any branch of science, and his observations will eonstantly add to his knowledge, while if he were ignorant, his observations might serve only to confirm his prejudices. We are not surprised when we observe how much better a man ean work with tools or instruments than without them. But the principles of science are the tools of observation, without which it is blundering and inefficient. Even if instruction of this sort in the public schools were to reach only a few minds, those few would render, a vast service to others by enlightening and directing their observation. If there be but one well-educated man in a district of intelligent farmers, the whole number are profited by his knowledge and his wisdom. Every neighbor sharpens his wits on this man's grindstone. They all likewise respect their occupation the more, because they can reckon one superior man in their ranks.

Geology is useful in explaining the resources of the country, and assists one in estimating the value of land in different localities, from the geological character of the place. But the principal advantages of this science are such as arise from its influence on the mind. Geology, above all other studies, engenders labits of reflection, and interests one in the observation of nature; and when we meet with a farmer who is a lover and a student of nature, though we might not warrant that he is a more successful practitioner than others, we are sure that he is satisfied with his occupation. Many young men become reconciled to the confinement of a counting-room in the city,
becanse it brings them in contact with the city's amusements. In like manner, those who are fond of the study of nature will love the exercises of the farm, which is a part of nature's domain.

It ought also to be expected that every practical farmer should understand the habits of the principal insect pests of his fields and orchards. A great amount of useful knowledge of this kind is frequently picked up by ingenious men, who have no acquaintance with the science of entomology. But had these persons been early instructed in the grammar of this science, their observations would have been conducted with method, and with much less effort they would have obtained more valuable knowledge of the habits of insects. As we have already intimated, one important method of instructing young men in the elements of these sciences, is to introdnce them into the district schools. Let there be a higher class to receive instruction in the grammar of each of the branches above enumerated.

It is only through the district schools that the generality of the rural population can be reached, during the period of youth, and the 
addition of these exercises would but slightly increase the expense of the schools. If a higher grade of qualifications was consequently required of the teachers, those only would be excluded who, under present circumstances, are unqualified for their task. Should lectures be established, according to the suggestion of an able writer* on this subject, they might be connected with recitations at the district schools ; and in some cases the teacher might be employed to lecture. Lecturing, however, is so expensive, that it would be difficult to make it sufficiently general, to convey instruction to the great mass of the farming population.

The tract system would seem to be admirably adapted to diffuse information on all scientific subjects. In connection with this it might be advisable to make offers of prizes to a certain number of individuals who should pass the best examination in the several departments of agricultural science and experience. Let ten prizes of equal amount, for example, be offered annually by each County Agricultural Society, to the ten individuals, members of a farmer's family, who will give the fullest, most correct and most intelligent answers to a series of questions to be proposed by the Society. The questions might be published as one of the series of tracts, to be followed, after the examination, by another containing the answers.

It is not probable that there would be a perplexing number of competitors for the prizes; the more, however, the better for the spread of information. Many young people of both sexes would be stimulated by these offers to make some progress in knowledge. Among farmers, as among other classes, there are some whose ignorance proceeds from a want of natural capacity. These must always remain mere drudges; they cannot be observers and thinkers. But the majority are ignorant not from a want of ability, but because their desire for knowledge has never been awakened. Such are the individuals upon whose minds, the offer of prizes of this kind would act in a favorable manner. The few, however, who are stimulated to engage in the studies and contend for the prizes, are not the only ones who would receive the benefit of them. Many a young man who jocosely ridicules his comrade, for collecting flowers and minerals, or chasing bugs, would assist him in lis explorations, and become the recipient of important knowledge.

Year after year similar offers might be made - for the best examinations respecting the names, the cultivation, and the comparative value of the different grasses; concerning the relations of chemistry and agriculture, the character of certain soils, rocks, fertilizers and other substances found in the earth; also, on the identity and habits of certain prominent insects which are injurious to the farm and the garden. By such methods young people are assisted in educating themselves; and it is on self-education, stimulated by the efforts of those who are watchful of the public welfare, that the chief reliance must be placed. They are induced to study by the excitement of their curiosity, consequent upon reading the questions proposed in the tract or the newspaper, and accompanying the offer of the prizes. Many

* Hon. George Boutwell. 
a happy family-cirele, during a leisure evening by the fireside, or while resting from their labors in the day, would employ themselves in asking these questions of each other, and puzzling out the answers.

But we must ever keep in mind, in our attempts to improve the farmer's education, that the main point is his practical profieiency. All other kinds of instruction must have a direet bearing towards this - the polar star of his educational course,-_and every aid he reeeives in his progress must take this direetion, filling his mind without diverting it firom its destination. All the tracts, therefore, on scientifie subjects, must be eminently praetical in their bearing; neither abstruse nor hypothetical. They must enlighten without confusing his mind, not perplexing it with notions, but establishing facts, whose relation to agriculture is perfectly clear. In the offer of prizes, the practical department should receive full attention; for any person would become more proficient in his art by aequiring a habit of assigning reasons for his practice.

Prizes of this character wonld serve also to elevate the business of farming in the opinions of men, by implying an acknowledgement, that intellect is required for the occupation. This is not implied in the award of premiums for agricultural essays ; for these are seldom written by farmers; and however expedient the offer, and however useful the essay, the farming community are often chagrined at seeing prizes of this kind carried off by one who, they well know, cannot equal themselves, in the knowledge of practical agriculture. Premiums should, therefore, be awarded, for intellectual exercises, in which farmers and the children of farmers should be the only competitors, and under such cireumstanees as would prevent the personal diffidence of the candidates from standing in the way of their success.

It may be objeeted to the offer of prizes for examinations in certain branches of knowledge, that some individuals would obtain the premium, who are excelled in industry by others who could not so readily explain the reasons for what they do, and that it would be better to give prizes only to industry. It may be remarked, however, in answer to this objection, that among qualities which are equally important, we should hold out the most encouragement to those which are the least common. Among our people, insufficient knowledge is more common than indolence; and it is not their industry that requires a spur, which is needful rather to their rational euriosity and intelligent observation. The intellectual habits of our countrymen are greatly injured by their propensity to devote all their attention and observation to the arts of trading and bargaining. Hence, they are "sharp," industrious and active, rather than intelligent. 'Those virtues and those habits require the most encouragement which do not grow up spontaneously. It should be added that our societies have always encouraged the useful virtue of industry by the award of premiuns for fat inimals, good crops and well-tilled fields. 'They should now stimulate industrious men to cultivate habits of intelligent observation, to learn to state the reasons for their practice, and to express their ideas with ease and perspicuity.

All vapid eulogies on the noble character of the farmer's oceupation amount to nothing; they are but so many idle words that do not serve 
in the least to increase its respectability. This end can be attained only by elevating the rural classes as intelligent beings. A farmer's business is no reproach to him in this country; no man, whatever may be his social position, is unwilling, if he be the son of a farmer, to make known his pedigree. But the time has not yet arrived, when it is regarded as a positive honor to be a farmer; and it will not arrive, until the farmers rise above the present standard of education. Agriculture, as all will admit, is a noble art; but the practice of it can be honorable only to those who are thoroughly acquainted with it, and who are intelligent citizens as well as successful farmers. 

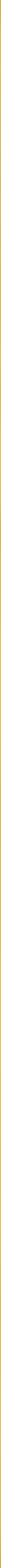


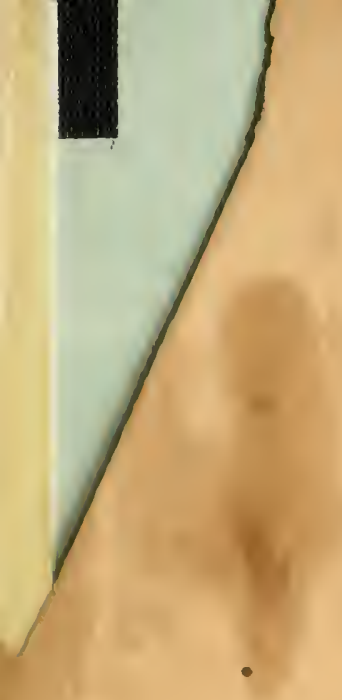

$\bullet$ 


